\title{
Tailoring nanostructured catalysts for electrochemical energy conversion systems
}

\author{
Aldo S. Gago a , Aurelien Habrioux and \\ Nicolas Alonso-Vante* \\ IC2MP UMR-CNRS 7285, University of Poitiers, 4 rue \\ Michel Brunet, B27-BP633, 86022, Poitiers, France, \\ e-mail: vante@univ-poitiers.fr \\ *Corresponding author
}

\begin{abstract}
This review covers topics related to the synthesis of nanoparticles, the anodic and cathodic electrochemical reactions and low temperature electrochemical energy devices. The thermodynamic aspects of nucleation and growth of nanoparticles are discussed. Different methods of chemical synthesis such as w/o microemulsion, Bönnemann, polyol and carbonyl are presented. How the electrochemical reactions take place on the surface of the catalytic nanoparticles and the importance of the substrate is put in evidence. The use of nanomaterials in low temperature energy devices such as $\mathrm{H}_{2} / \mathrm{O}_{2}$ polymer electrolyte or proton exchange membrane fuel cell (PEMFC) and micro-direct methanol fuel cell ( $\mu \mathrm{DMFC})$, as well as recent progress and durability, is discussed. Special attention is given to the novel laminar flow fuel cell (LFFC). This review starts with the genesis of catalytic nanoparticles, continues with the surface electrochemical reactions that occur on them, and finally it discusses their application in electrochemical energy devices such as low temperature fuel cells or Li-air batteries.
\end{abstract}

Keywords: electrochemistry; laminar flow fuel cell (LFFC); Li-air battery; micro-direct methanol fuel cell ( $\mu \mathrm{DMFC})$; nanoparticles; nucleation; proton exchange membrane fuel cell (PEMFC); synthesis.

\section{Introduction}

Electrochemical energy devices have been known since the 1800s, when the Italian physicist Alessandro Volta invented the galvanic cell or "voltaic pile". Thereafter, huge progress has been made in the development of devices for electrochemical energy conversion. As an example, a discovery by Mond and Langer [1] in 1889 showed that the increase of surface area of platinum electrodes in a coal gas/air fuel cell would enhance the current. This discovery boosted the new research

\footnotetext{
a Present address: Institute of Technical Thermodynamics/ Electrochemical Energy Technology, German Aerospace Center (DLR), Pfaffenwaldring 38-40, 70569 Stuttgart, Germany
}

area of the synthesis of divided materials. The development of materials at a nanometer scale [2-4] and the discovery of new ones $[5,6]$ during the past two decades paved the way to the development of low temperature energy devices. Such systems include polymer electrolyte or proton exchange membrane fuel cells (PEMFCs), micro-direct methanol fuel cells ( $\mu$ DMFC), laminar flow fuel cells (LFFCs) and Li-air batteries. The physicochemical properties of nanomaterials differ from their bulk equivalents so that the modified behavior of these nano-objects is of special interest in the field of electrocatalysis where activated charge transfer electrochemical reactions occur solely at the surface of such nanostructured materials. As a consequence, it is clear that catalytic properties of a nanodivided material not only depend on the chemical nature of the surface but also on their shape and size. These morphological parameters are interdependent. An important research activity devoted to the development of new methods of synthesis aiming at controlling the metallic atoms assemblies at the nanometer scale has been undertaken during the past three decades. Although catalytic electrochemical reactions occur at the surface of nanoparticles, the substrate also plays an important role in the performance of the electrochemical reactions, mass transport and conduction of charge generated from the reactions. The substrate prevents the agglomeration of nanoparticles, it increases their active surface area, and it also modifies the electronic properties, which is a crucial step in the mechanism of electrochemical surface reactions. All the aforementioned aspects will be discussed in detail in this work, going from the genesis of the nanoparticles to the final application in a device that converts chemical energy into electricity. The aim of this work is to present processes and methods for tailoring nanocatalysts for some electrochemical energy conversion systems such as low temperature fuel cells and Li-air batteries. In this review, we show how nanotechnology can be used to increase the output power of the electrochemical device using less amounts of materials.

Section 2 deals with the interest of metallic nanoparticles in the electrocatalysis field. Section 3 presents some thermodynamic aspects related to the nucleation and growth of nanoparticles. Additionally, this section presents some largely employed chemical methods for obtaining nanocatalysts. Section 4 deals with electrocatalytic aspects related to the oxidation of organic molecules and the reduction of molecular oxygen, also known as oxygen reduction reaction (ORR). As a consequence, all the concepts presented herein are used to develop both electrodes of fuel cell technologies and the cathode for Li-air batteries. Finally, sections 5 and 6 present the application of the previously developed notions to the generation of electrochemical energy and the currently encountered difficulties. Li-air batteries are low temperature 
electrochemical energy devices that are currently being supported with large amounts of resources and efforts. Given the importance of ORR for these systems, as well for PEMFCs, $\mu$ DMFCs and LFFCs, we have dedicated a subsection to the cathodes of Li-air batteries. The diagram in Figure 1 summarizes the main topics covered in this review.

\section{Metallic nanoparticles: their interest for electrocatalytic applications}

Nanoparticles are materials that have an application in heterogeneous catalysis and consequently in electrocatalysis. The unique properties of these nano-objects are mainly due to their high surface-to-volume ratio. It is well known that as the particles decrease in size, the number of reacting sites increases which is of interest for catalytic applications [7]. The reactivity is also modified as the relative ratio of catalytic sites is changed. Particularly, the relative number of edge and corner sites changes in addition to the ratio of crystallographic planes [8]. Additionally, as the size of nanoparticles reaches a few nanometers $(<5 \mathrm{~nm})$, the electronic and structural properties of these objects are greatly modified. The decrease in size implies a modification of the coordination number of surface atoms and consequently $d$ - $d$ orbital interactions are affected. In this regard, a contraction of the metal-metal bond length [9] is responsible for hybridization of a weaker number of wave functions of valence electrons [10]. This considerably affects the position of the d-band center in transition metals. As a result, the density of states, near the Fermi level of noble metal based catalysts, is modified. Based on these facts, several years ago, the Norskov group has developed the "d-band theory" [11-13]. This theory assumes that electronic states of the valence band are responsible for the reactivity on the surface of the nanoparticles. As a consequence, there is clear evidence that surface reactivity is not only determined by the chemical nature of the investigated metal but also by the properties of individual catalytic sites. Moreover, this

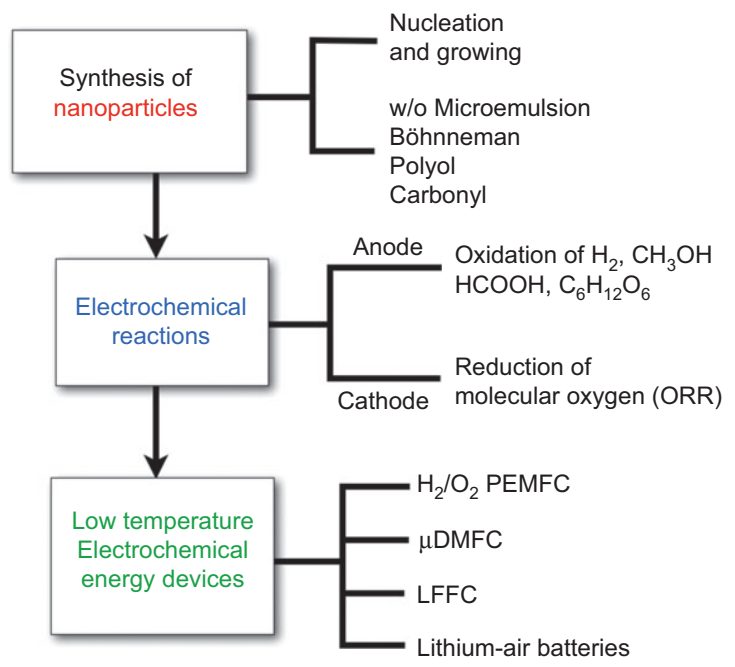

Figure 1 Main topics highlighted in this review. theory predicts that the position of the $d$-band center for a given metal determines the binding energy of a given adsorbate and is very useful in explaining the reactivity of some metal alloys [14, 15]. Finally, the crystallographic structure of nanoparticles is also affected by their size. For example, in the case of noble metals, which crystallize in a face-centered cubic lattice, the equilibrium shape is a truncated octahedron. However, decahedral- or icosahedral-like shaped nanoparticles are observed at small sizes $[16,17]$. This fact is of great interest for electrocatalysis because a change in shape implies a modification of the ratio of surface crystallographic planes, leading to a different reactivity.

\section{Synthesis of nanoparticles for electrocatalytic applications}

Two approaches are presently used to synthesize nanoparticles. The first one is the "bottom-up" pathway. This approach consists of building nanoparticles by assembling single atoms implying reduction/decomposition of metallic chemical precursors leading to the formation of nanoparticles from the aggregation of atoms. The second pathway, not discussed herein, is the "top-down" one, which consists of dividing bulk materials to particles. The "top-down" pathway includes energy intensive physical methods (high energy ball-milling, gas phase processes), which often involve the use of large amounts of matter. Moreover, acquiring size and shape control of synthesized nanoparticles needs a deep understanding of the synthesis process. Particularly, the tailoring of nanoparticles with uniform size is clearly related to the crystallization process (nucleation and growth steps). In this regard, thermodynamic aspects related to the formation of nanoparticles will be described.

\subsection{Nucleation and particle growth: thermodynamic aspects}

Generally, nucleation occurs solely when the solute concentration reaches a value for which the solution is supersaturated, allowing the precipitation process [18]. Different types of the nucleation process can be identified, namely, homogeneous, heterogeneous, and secondary nucleation. In the next subsections, on the basis of classical nucleation theory, an itemized description of each process will be given.

3.1.1. Homogeneous nucleation Homogeneous nucleation only occurs in the absence of a solid interface. It takes place in unstable supersaturated solutions [18]. The change of Gibbs free energy $(\Delta G)$ of the system generated by the formation of a nucleus can be described by using two competing parameters. The first one is related to the creation of a new volume $\left(\Delta G_{v}\right)$ and the second one is associated with the formation of a new surface $\left(\Delta G_{s}\right)$. Figure 2 shows a scheme of how the overall free energy $(\Delta G)$ evolves during the formation of a nucleus.

In the case of spherical nuclei $\Delta G$ can be described as follows [19]: 


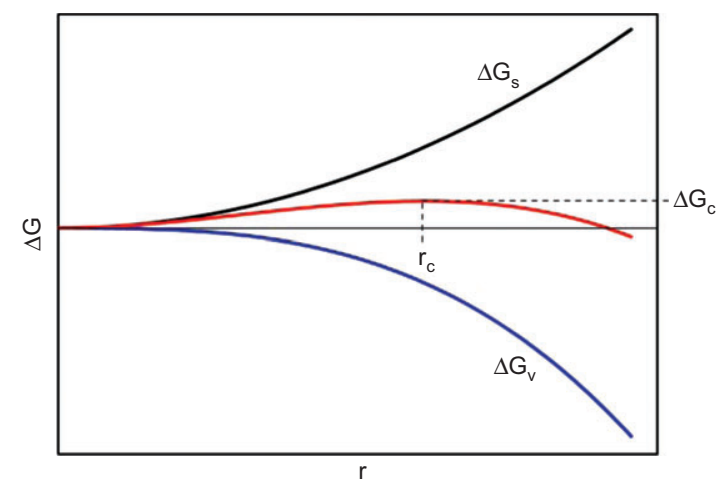

Figure 2 The overall free energy change $(\Delta \mathrm{G})$ during the formation of a nucleus of a nanoparticle.

$\Delta G=\Delta G_{v}+\Delta G_{s}=-\frac{4}{3} \pi r^{3} \times \frac{R T}{V_{m}} \operatorname{In}\left(\frac{[M]_{s}}{[M]_{e q}}\right)+4 \pi r^{2} \gamma$

where $r$ is the radius of the nuclei, $R=8.31 \mathrm{~J} \mathrm{~K}^{-1} \mathrm{~mol}^{-1}, T$ the absolute temperature, $V_{m}$ the molar volume of the crystal, $[M]_{s}$ the solute concentration at saturation, $[M]_{e q}$ the solute concentration at equilibrium, and $\gamma$ the surface energy per unit area. By calculating and examining the evolution of $\frac{d \Delta G}{d r}$, it can be seen that the evolution of $\Delta G$ is clearly dependent on the $\frac{[M]_{s}}{[M]_{e q}}$ ratio. If $\frac{[M]_{s}}{[M]_{e q}} \leq 1, \frac{d \Delta G}{d r} \geq 0$ and as a result $\Delta G$ increases with $r$, which implies that the nucleation process is not energetically favored. If $\frac{[M]_{s}}{[M]_{e q}}>1$, at first $\Delta G$ increases with $r$ and reaches a maximum value when the nucleus grows to a critical radius $r_{c}$, thereafter it decreases with further growth of the nucleus. Only clusters larger than the critical size are thermodynamically stable and these clusters can grow to form particles. Clusters that are not capable of performing this condition dissolve and thus a decrease in the overall free energy of the system is attained. From Eq. (1) and taking $\frac{d \Delta G}{d r}=0$ the critical radius $r_{c}$, can be given as:

$$
r_{c}=\frac{2 \gamma V_{m}}{R T \operatorname{In}\left(\frac{[M]_{s}}{[M]_{e q}}\right)}
$$

In this expression, the parameters governing the nucleation phenomenon are the surface free energy $\gamma$, the $[M]_{s} /[M]_{e q}$ ratio, and the reaction temperature, $T$. These three parameters can indeed affect the rate of nucleation and the magnitude of the activation barrier. Both conditions are necessary to obtain stable nuclei.

3.1.2. Heterogeneous nucleation During the process of heterogeneous nucleation, the nuclei are formed on the surface of a substrate, being either an impurity or a phase boundary. This latter phenomenon requires less energy than the homogeneous one [20]. In fact, the height of the nucleation barrier is affected by the heterogeneities. At these sites, the surface energy is low. The efficiency of the heterogeneity can be estimated taking into account parameters such as lattice mismatch or surface roughness. It is generally considered that the evolution of Gibb's free energy $\left(\Delta G_{\text {heterogenous }}\right)$ can be described [21] as follows:

$\Delta G_{\text {heterogenous }}=\Delta G_{\text {homogenous }} \times f(\theta)$

where $\Delta G_{\text {homogenous }}$ is the overall free energy for homogeneous nucleation and $f$ a function of the contact angle $\theta$. The numerical value of $f(\theta)$ is lower than 1 . The critical radius is considered to be the same for heterogeneous and homogeneous nuclei [21]. It is worth noting that very few studies take into account the microscopic parameters to model the interaction between the surface of the heterogeneity and the crystallizing fluid.

3.1.3. Secondary nucleation Secondary nucleation is a much more complicated approach and it takes place after the formation of primary seeds. It clearly has various origins. Firstly, in stirred media, the shock between crystals and release of crystalline dusts can lead to the production of new nuclei. Another source of new seeds is the adjacent layer to the solid-liquid interface. Some models have been developed to qualitatively describe the structure of this layer [22]. Quantitative models only consider this type of nucleation as a consequence of bidimensional growth and this process is described with theories related to the formation of seeds on a solid surface.

\subsubsection{Strategic routes to synthesize growth-controlled} nanoparticles According to the LaMer and Dinegar model [23], formation of nanoparticles occurs in two steps: nucleation and growth. Such formation is represented by the curve I in Figure 3. When the supersaturation decreases below a critical value, nucleation stops and particles begin to

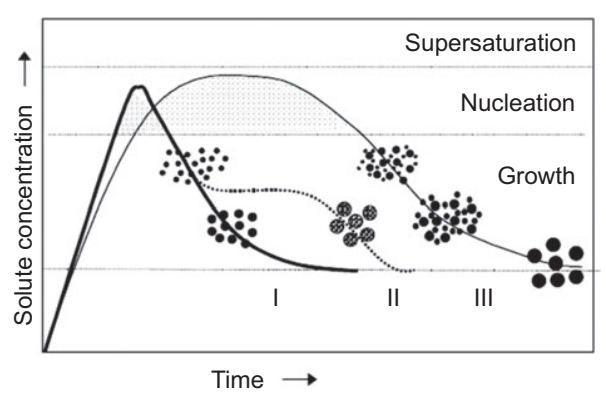

Figure 3 Mechanism of formation of uniform particles in solution: curve I, single nucleation and uniform growth by diffusion (classical model of LaMer and Dinegar [23]); curve II, nucleation, growth and aggregation of smaller subunits; curve III, multiple nucleation events and Ostwald ripening growth. Reprinted, with permission, from [24]. Copyright (2003) Applied Physics. 
grow by the addition of matter as long as the concentration of solute reaches the equilibrium concentration. During the growth process, small particles (with a radius just superior to the critical one) grow faster than the larger ones due to their huge thermodynamic driving force [18]. The first process corresponds to diffusional growth, which occurs until depletion of reactants. The second one corresponds to aggregation of the smallest subunits after classical nucleation and growth steps. This is presented in curve II of Figure 3.

The third growth process is presented in curve III of Figure 3. After multiple nucleation events the growth of particles occurs by Ostwald ripening. It corresponds to a selfsharpening growth process. This phenomenon can be clearly described by the Gibbs-Thomson equation [25]:

$C(r)=C^{0} \exp \left(\frac{2 \gamma V_{m}}{\gamma R T}\right)$

with $C(r)$ being solubility of a particle with a radius $r, C^{0}$ is solubility of the bulk phase, $T$ is temperature, $V_{m}$ is molar volume, and $\gamma$ is surface energy. From Eq. (4), it is clear that solubility of the particles is dependent on their size. During the Ostwald ripening phenomenon, the larger particles continue to grow whilst the smaller ones become smaller and eventually can dissolve if their size falls below the critical radius. At a further stage a discrimination of the size of the particles takes place. Moreover, from Figure 3 we observe that the rate of the process clearly decreases as particle size increases. As a result, the obtained size distributions are broad and multimodal most of the time. The modes are centered at high size values and others are focused on low size values.

To obtain a good monodispersion in size, it is considered as essential to temporally separate the step of nucleation from that of growth [26] even if the three previously presented growth processes (see Figure 3) can lead to the formation of uniform particles [24]. One of the most used synthetic routes to achieve this separation is the seed-mediated growth technique. In this method, preformed nuclei are introduced into the reactor and particles grow by precipitation of the precursor on the surface of the seed. Particles are formed by heterogeneous nucleation avoiding the homogeneous process [27]. Other techniques, such as injection of precursor into a hot solution [28] or heating up the batch reactor [29], have also been developed to synthesize size-controlled nanoparticles with a uniform size distribution. The first technique consists of quickly adding the chemical precursor into a hot solution containing a stabilizing agent. As a result, a high degree of supersaturation is rapidly reached before the nucleation rate decreases. The "heating up" method is slightly different as all the reactants are mixed together and the reactor is heated up until precipitation begins.

Another challenge consists of developing synthesis methods that are able to provide not only size-controlled particles but also shape-controlled particles. The main remaining difficulty lies in the low selectivity of the synthesis methods. The control of the shape of nanoparticles requires the control of the kinetic and thermodynamic parameters of the system. Using additives, varying the temperature or changing the concentration of reactants can tune up the thermodynamic parameters. The surface energy of nanoparticles needs to be taken into account to explain, predict and control the faceting occurring during the growth of metallic nanoparticles. The equilibrium shape of a nanoparticle in free space is defined by minimizing its surface energy. This latter assertion is a conclusion of Wullf's theorem [30]. As a consequence, if the synthesized material possesses an isotropic surface energy, its equilibrium shape is a sphere [31].

In the case of noble metals, which crystallize in a face-centered cubic lattice, the anisotropy of surface energy $\gamma$ results in the formation of particles with specific geometric shapes minimizing the surface free energy. In the case of face-centered cubic crystals, the surface energy of low index planes can be classified as follows: $\gamma_{111}<\gamma_{100}<\gamma_{110}$. Moreover, if $\frac{\gamma_{110}}{\gamma_{111}} \geq \frac{\sqrt{3}}{2}$,

the equilibrium shape of the particles is a truncated octahedron exhibiting six squared (100) faces and eight hexagonal (111) faces [32]. If this latter condition is not satisfied, there is formation of (110) domains at the edges [32].

Defects such as stacking faults and twins, which modify the shape of nanoparticles, can be included during the growth step. The twinning phenomenon is especially encountered in the synthesis of noble metal particles [33], because they are materials with low stacking fault energy [34]. Two types of twinning phenomena can be observed: lamellar twinning and cyclic twinning [35]. Lamellar twinning consists of the formation of successive parallel twin planes. Basically, lamellar twinning has a kinetic origin and often it results in the aggregation of small particles. Cyclic twinning has a thermodynamic origin and induces the growth of nanoparticles with icosahedral- and decahedral-like shapes. The junction of several tetrahedral forms these nanoparticles. As a consequence of the geometric generated space gap, the nanoparticles suffer from high internal stress leading to deformation of the crystals. However, the high mean internal strain is compensated by exposure of low energy planes. Formation of these types of particles is only possible if the following relationship is right $[21,31,36]$ :

$\gamma^{\prime}+\gamma_{\text {twin }}+\gamma_{\text {strain }}<\gamma$

where $\gamma^{\prime}$ and $\gamma$ are, respectively, surface free energies of nanoparticles with and without twins, $\gamma_{t w i n}$ is surface energy due to formation of a twin plane, and $\gamma_{\text {strain }}$ is surface energy induced by lattice distortion.

\subsection{Synthesis methods of nanoparticles by chemical solution deposition processes}

In this section, a non-exhaustive review of different synthesis methods allowing the preparation of surface-surfactant free metallic nanoparticles is given. Indeed, a required condition to elaborate electrocatalysts with a high active surface area is that this surface must be free of organic contaminants. Thus, removal of surfactant molecules from all catalytic sites without modifying structural properties of the nanoparticle is still a great challenge. 
To obtain acceptable electrochemical performances it is necessary to make a good choice of the synthesis method. Stabilization of the particles must be achieved by the use of organic molecules, which are easily removable via a "soft cleaning process".

3.2.1. Water-in-oil microemulsion This method was initially developed for the synthesis of platinum nanoparticles. Boutonnet et al. reported, for the first time in 1982, the use of w/o microemulsions to synthesize metallic nanoparticles [4]. More recently, w/o microemulsions have been used to synthesize one-metal center nanoparticles of $\mathrm{Pd}, \mathrm{Au}$ and $\mathrm{Pt}$ [37], as well as two-metal centers such as Pt-Ru [38], Pt-Pd [39] and Pt-Au [40].

A microemulsion results from the mixing and shaking of two non-miscible liquids. The suspension is maintained thermodynamically stable due to the presence of a surfactant molecule. According to Capek [37], when the surfactant concentration exceeds the critical micellar concentration, reverse micelles can be formed. These reverse micelles act as microreactors, allowing the stabilization of water droplets in an oil phase. Thus, the mixing of two microemulsions, one containing the metallic precursors (microemulsion I) and the other one with the reducing agent (microemulsion II), leads to the formation of metallic nanoparticles. The precursors and the reducing agent have to be in aqueous phase. The reduction process occurs because of the collision between water droplets, which is accompanied by exchange of intramicellar media. The synthesis process has been deeply described by Capek [37] and is summarized by the scheme shown in Figure 4. The nucleation of nanoparticles as well as the growth process occurs inside the micelles. Consequently, the properties of the micelles are directly responsible for the size of nanoparticles.

To give a comprehensive explanation of the formation of nanoparticles, two models have been proposed [41]. The first one, based on the model of Lamer [23], assumes that the first step corresponds to the nucleation process. Then, the process of growth of nanoparticles occurs. The model supposes that size of nanoparticles continuously increases with the micellar precursor concentration. The second model is based on the thermodynamic stabilization of nanoparticles due to the surfactant molecules. Numerical simulations suggest that the two different mechanisms coexist according to the concentration of reactants [42]. At high concentrations the nucleation and growth step occur successively, whereas at low concentrations
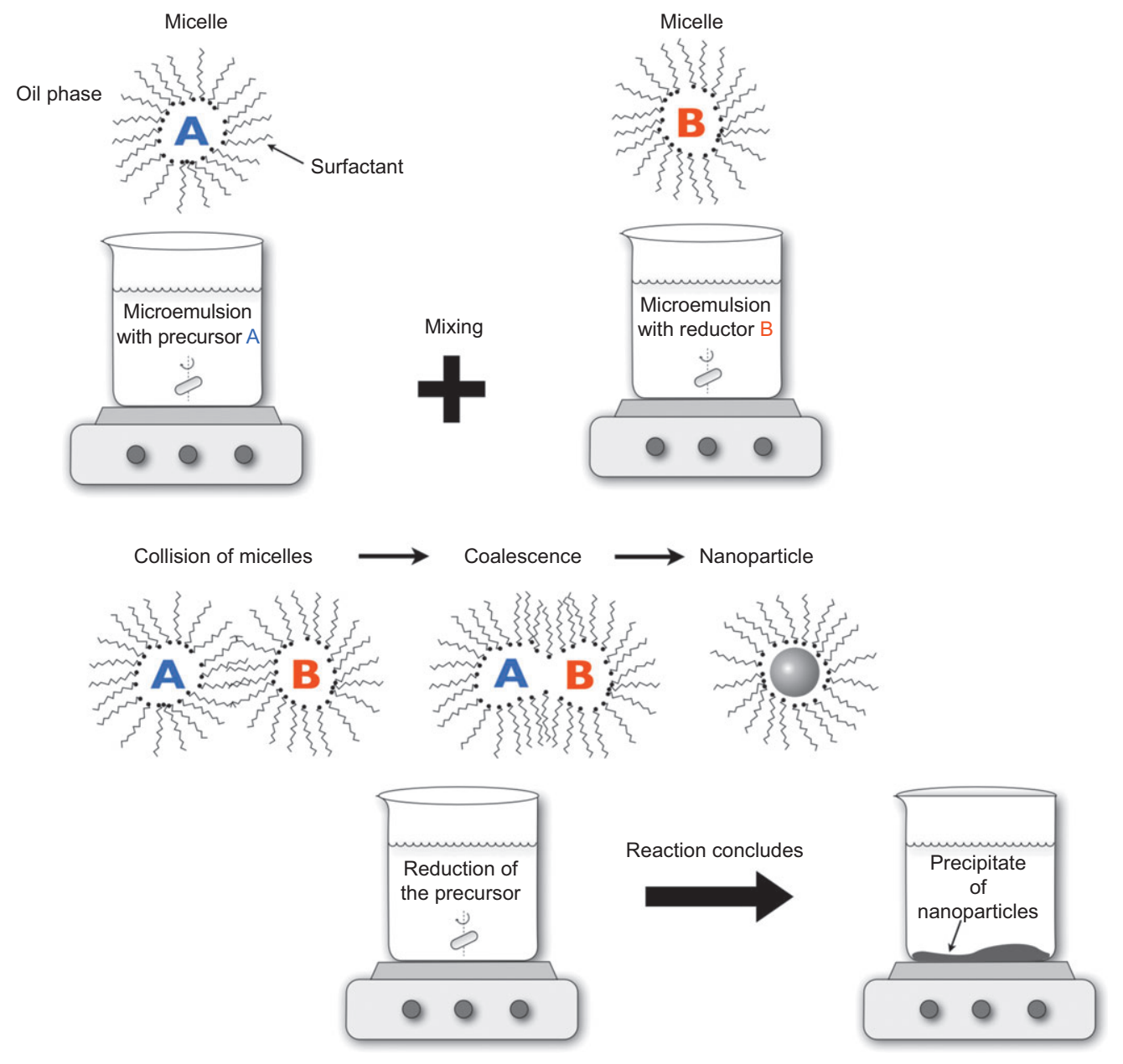

Figure 4 Formation of metallic nanoparticles by water-in-oil microemulsion process. 
two processes take place simultaneously. These simulations also showed that particles begin to grow by autocatalytic effect before growing by coalescence of nuclei (Ostwald ripening). The different parameters affecting the properties of micelles and consequently the size of nanoparticles have been identified [43]. The water-to-surfactant ratio is responsible for considerably modifying the size of the micelles. The size increases when adding water and decreases with the addition of more surfactant, which results in the formation of a higher number of micelles.

Another important parameter in the synthesis of metallic nanoparticles by the w/o microemulsion technique is the chemical nature of the surfactant molecule. The use of an ionic surfactant, for example, sodium bis(2-ethylhexyl) sulfosuccinate, could lead to the existence of electrostatic repulsion between reactants contained inside the micelle and the surface of the micelle itself. This coulombic interaction provokes overconcentration of areas that are responsible for modifying the nucleation rate. This phenomenon can be avoided by using a non-ionic surfactant $\left(\mathrm{Brij}^{\oplus}{ }^{\circledR 0}\right)$. The nature of the surfactant as well as the olefin used influence the properties of the micellar film, which directly determines water solubility in the micellar medium [44], thus noticeably affecting the rate of intermicellar exchanges [42]. Finally, the nature of the reducing agent is also a key parameter, which needs to be taken into account because it states the rate of the nucleation step. The most common reducing agents are hydrazine [4] or sodium borohydride [38].

3.2.2. Bönnemann method This colloidal method was developed and described by Bönnemann and coworkers [3, 45] and has been extensively used to synthesize highly active nanocatalysts, which can be used in heterogeneous catalysis. It has been widely used for the synthesis of monodisperse platinum-based nanoparticles for electrocatalysis.

The method can be described as follows: anhydrous metallic precursors are solubilized into an organic solvent, which is tetrahydrofuran (THF) before being treated with the reducing agent (alkylammonium organoborate). Formation of the colloidal suspension takes place according to the following equation:

$M X_{n}+n \mathrm{~N}_{4} \mathrm{Bet}_{3} \mathrm{H} \rightarrow M\left(\mathrm{~N}_{4} X\right)_{n}+n \mathrm{BEt}_{3}+n / 2 \mathrm{H}_{2}$

where $M$ is the metal, $X$ is a halogen element $(\mathrm{Cl}, \mathrm{Br}), n=2$, 3 , and $R$ is the alkyl chain, which can contain from 4 up to 20 carbon atoms. The Bönnemann method does not require an external stabilizing agent because the ammonium salt produced during the reduction process plays the role of the surfactant molecule.

3.2.3. Polyol method The polyol method was initially devoted to the synthesis of cobalt and nickel particles [46]. It was later developed for the synthesis of platinum-based nanocatalysts [47]. This process uses the reductive properties of polyol molecules such as ethylene glycol and glycerol, which also play the role of solvents. The most commonly used polyol is ethylene glycol (EG). Metallic salts are solubilized into an EG solvent in which sodium hydroxide was previously dissolved to increase the $\mathrm{pH}$ value. The oxide or hydroxide species are formed afterwards. Later the dehydration of the EG molecule into acetaldehyde, Eq. (7), is responsible for reduction of metallic precursors into metal $(M)$, Eq. (9). The whole process can be described by the following equations [47]:

$$
\begin{aligned}
& \mathrm{CH}_{2} \mathrm{OH}-\mathrm{CH}_{2} \mathrm{OH} \leftrightarrow \mathrm{CH}_{3}-\mathrm{CHO}+\mathrm{H}_{2} \mathrm{O} \\
& \mathrm{CH}_{2} \mathrm{OH}-\mathrm{CH}_{2} \mathrm{OH}+2 \mathrm{HO}^{-} \leftrightarrow \mathrm{CH}_{2} \mathrm{O}^{-}-\mathrm{CH}_{2} \mathrm{O}^{-}+\mathrm{H}_{2} \mathrm{O} \\
& \mathrm{MO}_{2}+4 \mathrm{CH}_{3}-\mathrm{CHO} \leftrightarrow M+2 \mathrm{CH}_{3}-\mathrm{CO}-\mathrm{CO}-\mathrm{CH}_{3}+2 \mathrm{H}_{2} \mathrm{O}
\end{aligned}
$$

As can be seen from Eq. (8), the acid base reaction leads to the formation of glycolate ions during the synthesis process. These ions allow the stabilization of the metallic particles because the ions adsorb onto metallic surfaces. As a result, this synthesis method does not need the use of a surfactant molecule and therefore it is an interesting way to obtain "electrochemically clean" nanomaterials.

3.2.4. Carbonyl method This method of synthesis is very useful for the synthesis of clean and size-controlled electrocatalysts. The carbonyl method [48, 49] takes advantage of the reactivity of metal carbonyls in solvents to obtain metallic clusters. It has been used to synthesize $\mathrm{Ru}$ [50] or Pt-based catalysts for electrocatalytic purposes. Figure 5 shows a scheme of all the steps for the synthesis of Pt nanoparticles supported on carbon Vulcan XC-72. In short, platinum carbonyl $\left[\mathrm{Pt}_{3}(\mathrm{CO})_{6}\right]_{5}{ }_{5}^{2-}$ is prepared by mixing specific quantities of $\mathrm{Na}_{2} \mathrm{PtCl}_{6} \times 6 \mathrm{H}_{2} \mathrm{O}$ with sodium acetate $(\mathrm{mol}$ ratio of $\mathrm{NaAc} / \mathrm{Pt}=6)$ in methanol solution under $\mathrm{CO}$ atmosphere, for $24 \mathrm{~h}$. Thereafter, activated carbon Vulcan XC72 is added to the above solution and stirred for another $12 \mathrm{~h}$ under nitrogen atmosphere. The final product, nanostructured $\mathrm{Pt} / \mathrm{C}$, is washed, filtered and dried. A transmission electron microscopy (TEM) image is shown at the end of these steps in the scheme of Figure 5. The Pt nanoparticles are very well dispersed on the carbon substrate and they have a uniform particle size of $2.0 \pm 0.9 \mathrm{~nm}$.

\section{Anodic and cathodic reactions}

Electrocatalysis was introduced during the 1960s to study electrochemical reactions occurring in a fuel cell. A fuel cell is an electrochemical device capable of converting chemical energy into electric energy. This conversion takes place because of oxidation of a fuel at the anode and reduction of an oxidant at the cathode. Currently, numerous types of fuel cells exist, which differ from each other by their working temperature, their delivered power density, and the fuel they use. In section 5 different types of low temperature fuel cells will be discussed. In this review, only hydrogen $\left(\mathrm{H}_{2}\right)$, methanol $\left(\mathrm{CH}_{3} \mathrm{OH}\right)$, formic acid $(\mathrm{HCOOH})$ and glucose $\left(\mathrm{C}_{6} \mathrm{H}_{12} \mathrm{O}_{6}\right)$ are taken into account as fuels. These organics are of great interest because their related thermodynamic data offers promising perspectives for fuel cell applications (see Table 1). 


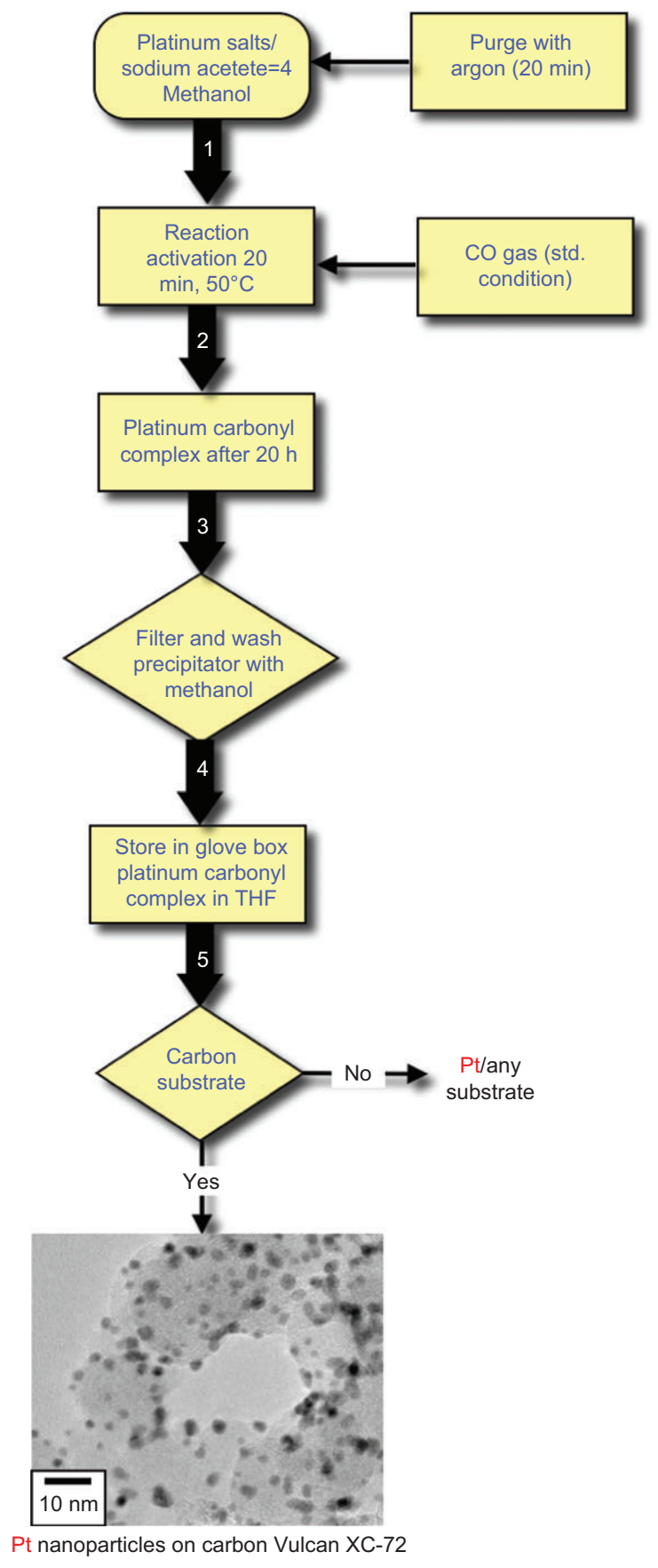

Figure 5 Steps for the synthesis of Pt nanoparticles supported on carbon Vulcan XC-72, via the carbonyl chemical method.
The fuels above have high energy densities $\left(\Delta G^{0}\right)$ as well as high theoretical cell voltages $\left(E^{0}\right)$ and high specific energies $(W)$. Among all the fuels listed in Table 1, glucose is of special interest because it is a non-toxic, cheap, primary fuel. It is directly obtained from biomass and there is no need of additional chemical transformations. However, all fuel cell technologies that use the fuels presented in Table 1 need efficient nanostructured catalysts capable of improving the kinetics of fuel increasing oxidation current densities and minimization of overpotentials. The development of these nanostructured catalysts is still in progress. Electrocatalytic issues associated with the use of each fuel will be discussed in the following section.

\subsection{Oxidation of small organics}

4.1.1. Methanol and formic acid oxidation Electrooxidation of methanol has been extensively studied in the past years for DMFC. It was rapidly shown that platinum was the best one-metal center material to oxidize methanol in acidic medium [54-56]. The oxidation mechanism can be described as shown in the scheme of Figure 6. On the surface of platinum, the complete oxidation of methanol into $\mathrm{CO}_{2}$ is achieved according to a dual path mechanism. Initially, the direct pathway does not involve the formation $\mathrm{CO}_{\text {ads }}$ species and therefore the indirect pathway leads to the formation of $\mathrm{CO}_{\text {ads }}$. The direct pathway may also involve the formation of side products, such as formaldehyde or formic acid [57, 58], resulting from incomplete oxidation of methanol (see Figure 6). The first step of the mechanism is adsorption of methanol at low overpotentials, immediately followed by its dehydrogenation. This second step involves three neighboring platinum sites [59] and generates formation of $\mathrm{CHO}_{\mathrm{ads}}$. This latter intermediate is unstable and rapidly leads to formation of $\mathrm{CO}_{\text {ads }}$, which is the major cause of poisoning Pt during the catalytic process. Water adsorption in the vicinity of the blocked catalytic site allows oxidation of $\mathrm{CO}_{\text {ads }}$ to $\mathrm{CO}_{2}$. Summing up, the determining rate step of the oxidation process is the oxidation of adsorbed CO [60-62].

The addition of a second metal to platinum allows the water adsorption in the vicinity of the poisoned catalytic site. Among several possibilities, the synthesis of Pt-Ru nanoparticles has been extensively investigated [63]. This type of catalyst shows a bifunctional mechanism in which platinum is responsible for dehydrogenation of methanol and ruthenium provides $\mathrm{OH}$ species in the vicinity of platinum sites. These species allow the oxidation of $\mathrm{CO}$-like species into $\mathrm{CO}_{2}$ at

Table 1 Thermodynamic data associated with complete combustion of fuel in pure oxygen accompanied with exchange of $\mathrm{n}$ electrons.

\begin{tabular}{|c|c|c|c|c|c|c|c|}
\hline Fuel & Chemical formula & $\begin{array}{l}\mathrm{M} / \mathrm{g} \\
\mathrm{mol}^{-1}\end{array}$ & $\Delta_{r} G^{0} / \mathrm{kJ} \mathrm{mol}^{-1}$ & $\mathrm{n}$ & $E^{0} / \mathrm{V}$ & $W / \mathrm{Wh} \mathrm{kg}^{-1}$ & $\eta / \%$ \\
\hline Hydrogen & $\mathrm{H}_{2}$ & 2 & -237.4 & 2 & 1.23 & 32,802 & 83 \\
\hline Methanol & $\mathrm{CH}_{3} \mathrm{OH}$ & 32.04 & -702 & 6 & 1.21 & 6073 & 97 \\
\hline Formic acid & $\mathrm{HCOOH}$ & 46.03 & -270 & 2 & 1.40 & 1630 & 100 \\
\hline Glucose & $\mathrm{C}_{6} \mathrm{H}_{12} \mathrm{O}_{6}$ & 180.16 & -2870 & 24 & 1.24 & 4430 & 100 \\
\hline
\end{tabular}

$\Delta_{r} G^{0}$ represents energy density; $W$ is theoretical specific energy of the fuel; and $\eta$ is theoretical energy conversion efficiency. Values are either calculated or extracted from [51-53]. 


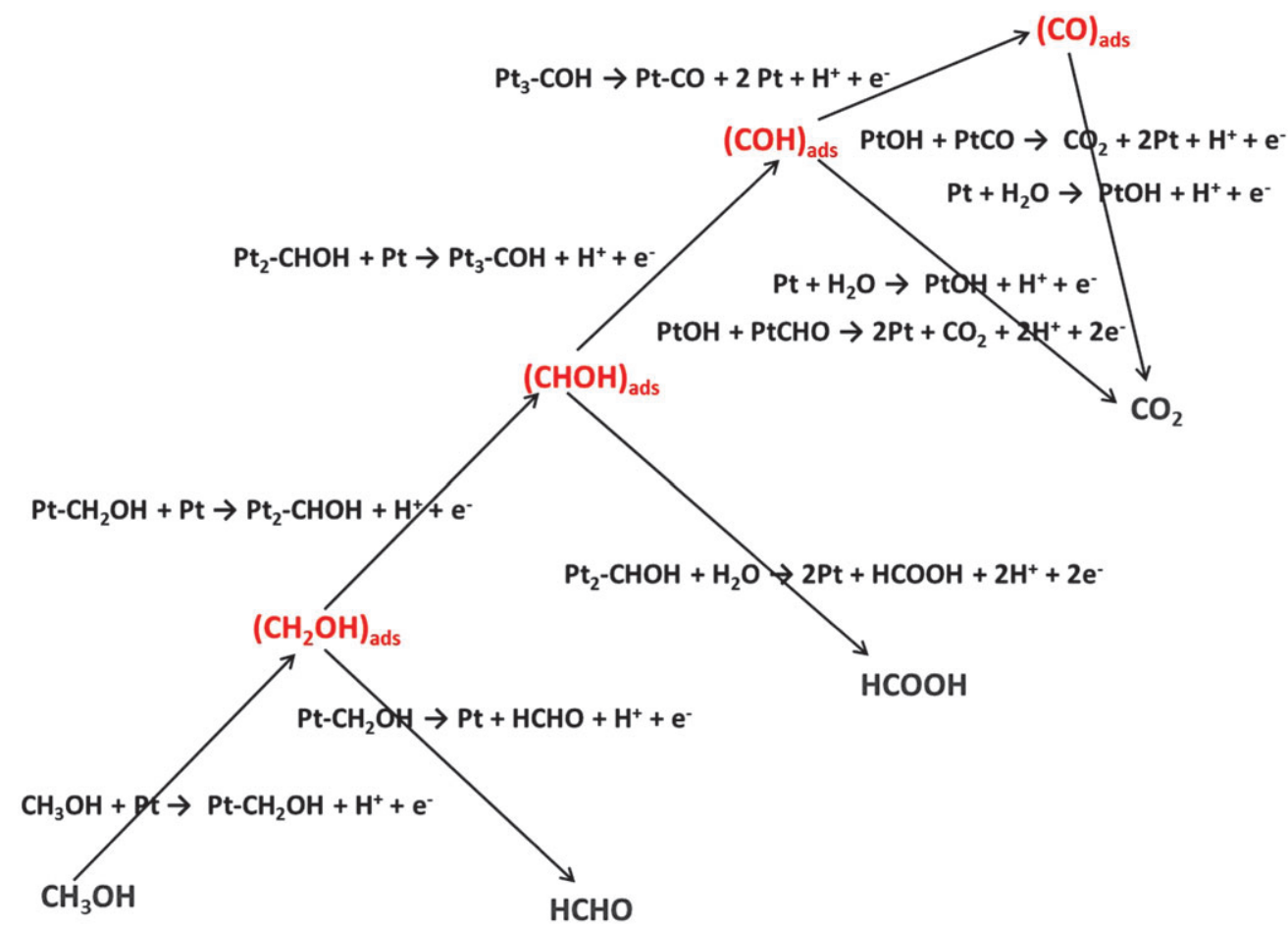

Figure 6 Electrochemical mechanism of methanol oxidation at platinum surface.

lower potentials than on monometallic surfaces. To synthesize this Pt-Ru based materials, different synthetic routes have been investigated such as the colloidal synthesis method [64, 65], microwave irradiation [66], electrodeposition [67] or microemulsions [68]. Other bimetallic nanomaterials such as Au-Pt nanoparticles have been used to oxidize methanol. In the case of Au-Pt catalyst, a synergistic effect could occur between gold and platinum depending on the synthesis method $[69,70]$. As a result, a shift of the $d$-band center of platinum may occur. This shift is evidence for a weaker Pt-CO bond [71] and consequently the kinetics towards methanol oxidation is improved.

Formic acid is an interesting fuel for fuel cell technologies because contrary to methanol it is non-toxic and exhibits a low crossover [72] in direct formic acid fuel cells (DFAFCs). The phenomenon of fuel crossover will be discussed in subsection 5.2. The electrochemical oxidation of $\mathrm{HCOOH}$ on platinum surfaces leads to the formation of $\mathrm{CO}_{2}$. As for $\mathrm{CH}_{3} \mathrm{OH}$, the reaction involves a dual pathway mechanism. The direct mechanism (dehydrogenation of formic acid) occurs without involving $\mathrm{CO}_{\text {ads }}$-like species, whereas the indirect pathway (dehydration of formic acid) implies the formation of $\mathrm{CO}$ poisoning species [73, 74]. In this regard, catalysts capable of improving the oxidation kinetics of formic acid in acidic media are of the same chemical nature than those used to oxidize methanol.

4.1.2. Glucose oxidation Numerous studies concerning electro-oxidation of glucose are currently being carried out. Glucose is a cheap primary fuel possessing a high energy density of $4430 \mathrm{Wh} \mathrm{kg}^{-1}$ [51]. Assuming the exchange of 24 electrons per glucose molecule, the electrochemical oxidation of $\mathrm{C}_{6} \mathrm{H}_{12} \mathrm{O}_{6}$ leads to the formation of $\mathrm{CO}_{2}$. Nevertheless, the complete oxidation of glucose has never been achieved and it often leads to the formation of gluconic acid accompanied by the exchange of only two electrons according to:

$\mathrm{C}_{6} \mathrm{H}_{12} \mathrm{O}_{6}+2 \mathrm{HO}^{-} \rightarrow \mathrm{C}_{6} \mathrm{H}_{10} \mathrm{O}_{6}+2 \mathrm{H}_{2} \mathrm{O}+2 \mathrm{e}^{-}$

Moreover, the process of oxidation of $\mathrm{C}_{6} \mathrm{H}_{12} \mathrm{O}_{6}$ is enhanced in alkaline medium. This enhancement is clearly related to the mutarotation equilibrium and can be correlated with the predominance of $\beta$-D-glucose anomer in alkaline medium. This later seems to be the most active form among the D-glucose anomers [75]. The chemical structure of the anomers is shown in Figure 7. The origin of the singular activity of the $\beta$-D-glucose anomer has been associated with its favorable geometry.

Most of the studies on the electrochemical oxidation of glucose are devoted to understanding the reaction mechanism on platinum surfaces $[76,77]$. As previously mentioned, oxidation of glucose on platinum mostly leads to formation of the

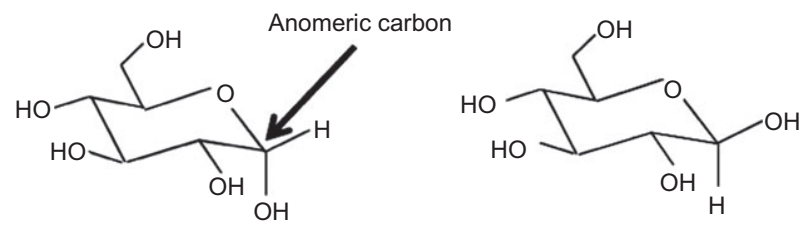

$\alpha$-Anomer of D-glucose molecule

$\beta$-Anomer of D-glucose molecule

Figure 7 Representation of two anomers of the D-glucose molecule. 
two-electron oxidation product, which is gluconic acid [77, 78]. The surface reaction involves a dehydrogenation step of the anomeric carbon [79] of glucose molecule which occurs at very low overpotentials (i.e., $0.2 \mathrm{~V}$ vs. RHE). The low overpotential oxidation process is of great interest for fuel cell applications. However, platinum surfaces are very sensitive to poisoning with chemisorbed intermediate species [80, 81], resulting in poor reaction kinetics. To enhance oxidation rate, the surface of Pt was modified by heavy atoms such as $\mathrm{Tl}, \mathrm{Pb}$, Bi, W [82].

The kinetics of electro-oxidation of glucose can also be improved on $\mathrm{Pt}$ nanoparticles alloyed with $\mathrm{Rh}, \mathrm{Pd}, \mathrm{Pb}, \mathrm{Au}$ [76] or $\mathrm{Bi}, \mathrm{Ru}, \mathrm{Sn}$ [83]. The second metal is capable of either maintaining the activity of platinum or providing an oxygenated species that allows desorption of poisonous species. Furthermore, the use of Au-Pt nanoparticles has been extensively studied [70, 84]. It has been demonstrated that a synergistic effect between gold and platinum was responsible for increasing the rate of catalytic reactions [85]. The nanoparticles of Au-Pt have been synthesized either by microemulsion [84], co-deposition of metallic salts [86] and colloidal route [87].

\subsection{Oxygen reduction reaction (ORR)}

The ORR is very complex and involves a number of different adsorbate intermediates [88, 89]. This process is considered to be one of the most important electrochemical processes due to its central role in electrochemical energy conversion devices. Furthermore, molecular oxygen represents the most convenient and abundant oxidant for conversion of solid, liquid and gas fuels. For many years it has been the focus of interest to the low temperature fuel cell (cf. sections 5.1, 5.2, 5.3) as well as battery community (cf. section 5.4); first, in the context of alkaline fuel cell research, then phosphoric acid fuel cells and Zn/air batteries, and then in the domain of polymer electrolyte membrane fuel cells. The challenges in the study of the ORR continue to be the establishment of the reaction mechanism [90] as well as the identification of a highly active and stable catalyst material in nanodivided form [21, 91-95]. At the fuel cell cathodes the oxygen reduction reaction is intrinsically slow and highly irreversible, thus leading to a high activation polarization, which drastically reduces the cell voltage, hence, the efficiency of the system (cf. sections 5.1, 5.2). Unlike on well-defined catalyst materials, carbon supported nanocatalysts on the basis of platinum group metals (PGMs) as well as non-platinum group metals (NPGMs) have been devised. Within these groups, the precious metal group (PMG) [96, 97] and the non-precious metal group (NPMG) $[98,99]$ are established. The electronic property of the supported catalytic centers either one- or twometals (nanoalloys) will determine the degree of selectivity or tolerance to small organics for the ORR process (cf. sections 5.1, 5.2, 5.3). As recently reviewed [91], the charge transfer of the overall ORR, Eq. (14), will depend on the electrolyte nature and on the catalyst centers, and the generation of intermediate species can be depicted by a series of reactions leading to the product of hydrogen peroxide [90].

$$
\begin{aligned}
& \cdot+\mathrm{O}_{2} \rightarrow \cdot-\mathrm{O}_{2 \text { ads }} \\
& \cdot-\mathrm{O}_{2 \text { ads }}+\left(\mathrm{H}^{+}+\mathrm{e}^{-}\right) \rightarrow \cdot-\mathrm{O}_{2} \mathrm{H}_{\text {ads }} \\
& \cdot-\mathrm{O}_{2} \mathrm{H}_{\text {ads }}+\left(\mathrm{H}^{+}+\mathrm{e}^{-}\right) \rightarrow \cdot-\mathrm{O}_{\text {ads }}+\mathrm{H}_{2} \mathrm{O} \text { or }\left(\cdot-\mathrm{O}_{2} \mathrm{H}_{2}\right) \\
& \cdot-\mathrm{O}_{\text {ads }}+\left(\mathrm{H}^{+}+\mathrm{e}^{-}\right) \rightarrow \cdot-\mathrm{OH}_{\text {ads }} \\
& \cdot-\mathrm{OH}_{\text {ads }}+\left(\mathrm{H}^{+}+\mathrm{e}^{-}\right) \rightarrow \cdot+\mathrm{H}_{2} \mathrm{O}
\end{aligned}
$$

where any catalytic site is represented by ".". This mechanism involves the production of hydrogen peroxide, Eq. (11c). Indeed, analysis of most PMG or NPMG supported nanodivided catalyst materials reveal that the ORR proceeds in an associative process, and that the increased amount of detected hydrogen peroxide is related to the decrease of catalyst loading or site density [91].

\subsection{Catalyst support}

The support for the catalytic nanoparticles plays an important role on performance and stability of PEMFCs. The catalytic nanoparticles of the electrodes of the PEMFCs are usually supported on electronic conducting substrates such as nanostructured carbon [92, 100-107] and carbon nanotubes [108111]. In the next subsections, different supports for catalytic nanoparticles are presented and discussed.

4.3.1. Traditional carbon-based supports Carbon black based support, namely Vulcan XC-72, is the most widely used catalyst support due to its high surface area and good electronic conductivity. However, carbon is highly reactive and oxidizes to $\mathrm{CO}_{2}[112,113]$ :

$\mathrm{C}+2 \mathrm{H}_{2} \mathrm{O} \rightarrow \mathrm{CO}_{2}+4 \mathrm{H}^{+}+4 \mathrm{e}^{-} \quad E^{\circ}=0.207 \mathrm{~V}$

Furthermore, carbon Vulcan XC-72 corrodes electrochemically at $0.96 \mathrm{~V}$ vs. RHE [114], which is lower than the overpotential for the ORR in acidic media. This reaction occurs at the cathode of a PEMFC. Indeed, the cathode of a PEMFC can reach potentials higher than $1 \mathrm{~V}$ and therefore, at the cathode, the atoms of carbon at the interface with platinum oxidize to produce $\mathrm{CO}_{2}$. Consequently, the $\mathrm{Pt}$ nanoparticles move or dissolve in the $\mathrm{H}_{2} \mathrm{O}$ produced by the PEMFC. This negative effect results in agglomeration of the metal nanoparticles and the electrochemical active surface (EAS) is diminished. The aftermath is a dramatic loss in the performance of the PEMFC over time $[115,116]$.

Novel supports for catalytic nanoparticles of the cathode of a PEMFC have thus to be developed. The most suitable catalyst support is expected to have good electronic conductivity and high electrochemical stability, that is, resistance to corrosion. Basically, the requirements that a catalyst support has to meet are:

- High electrical conductivity [117].

- Strong interaction with the catalytic nanoparticles, that is, strong metal-support interaction (SMSI) [118-120]. This interaction improves the electrocatalytic activity of the metal nanoparticles towards the ORR. 
- Triple phase boundary and large surface area [117]. Indeed, the support has to have a mesoporous structure to enable the Nafion ${ }^{\circledR}$ ionomer, the catalyst and the polymer membrane to come close to the reactants.

- Resistant to electrochemical corrosion $\left(E_{\text {corr }}\right.$ higher than 1.2 $\mathrm{V}$ vs. RHE). The corrosion phenomenon occurs mostly during the startup and shutdown processes [121].

- Good water management with the capability to avoid flooding.

- Research on supports for catalytic nanoparticles has been focused on three categories of materials: ceramics, carbon nanotubes and more recently graphene.

4.3.2. Ceramics Many oxide ceramics and carbides have been studied as supports for electrocatalytic nanoparticles. Among these materials, one of the most promising ceramics to be used as catalyst support is $\mathrm{Ti}_{1-\mathrm{x}} \mathrm{W}_{\mathrm{x}} \mathrm{O}_{2}[122,123]$. The substitution of $\mathrm{Ti}$ atoms by $\mathrm{W}$ in $\mathrm{TiO}_{2}$ greatly alters the position of the energy bands of the semiconductor [124]. The addition of $\mathrm{W}$ renders a metallic character to $\mathrm{TiO}_{2}[124$, 125]. The modified oxide, $\mathrm{Ti}_{1-\mathrm{x}} \mathrm{W}_{\mathrm{x}} \mathrm{O}_{2}$ can be produced as a nanostructured powder [122, 126-128] and in thin films $[125,129,130]$. The carbon-free catalyst $\mathrm{Pt} / \mathrm{Ti}_{07} \mathrm{~W}_{0.3} \mathrm{O}_{2}$ has been evaluated for the ORR in acidic medium [122]. Figure 8A,B shows the cyclic voltammetry (CV) and the ORR characteristic of $\mathrm{Pt} / / \mathrm{Ti}_{0.7} \mathrm{~W}_{0.3} \mathrm{O}_{2}$ catalyst in acidic medium, respectively. For comparison purposes $\mathrm{Pt} / \mathrm{C}$ is also shown. The support of $\mathrm{Ti}_{0.7} \mathrm{~W}_{0.3} \mathrm{O}_{2}$ not only enhances the electrocatalytic activity of Pt but, as can be expected, the tolerance to $\mathrm{CO}$ poisoning is also improved [123]. Indeed, due to a bifunctional mechanism, metal nanoparticles have shown to be tolerant to small organics when supported on $\mathrm{TiO}_{2}$ [131-135]. However, so far, the long-term stability of $\mathrm{Pt} / \mathrm{Ti}_{1-\mathrm{x}} \mathrm{W}_{\mathrm{x}} \mathrm{O}_{2}$ has not been explored. In addition to $\mathrm{Ti}_{1-\mathrm{x}} \mathrm{W}_{\mathrm{x}} \mathrm{O}_{2}$, other ceramics such as $\mathrm{SiO}_{2}$ [136], $\mathrm{NbO}_{2}$ [137], $\mathrm{MnO}_{\mathrm{x}}[138], \mathrm{WO}_{\mathrm{x}}[139,140], \mathrm{SnO}_{2}$ [141] and $\mathrm{TiO}_{x}[119,120,132,138,140,142-147]$ have been used as support for electrocatalytic nanoparticles. They have proven to be very resistant to the electrochemical corrosion, but the electronic properties of these materials are not as good as those of carbon. Given that the electronic conductivity of carbon has not been surpassed by the novel ceramic supports, composites such as $\mathrm{TiO}_{2}$-carbon $[119,120]$ or $\mathrm{WO}_{\mathrm{x}}$-carbon [148] have been developed. These composites, when used as
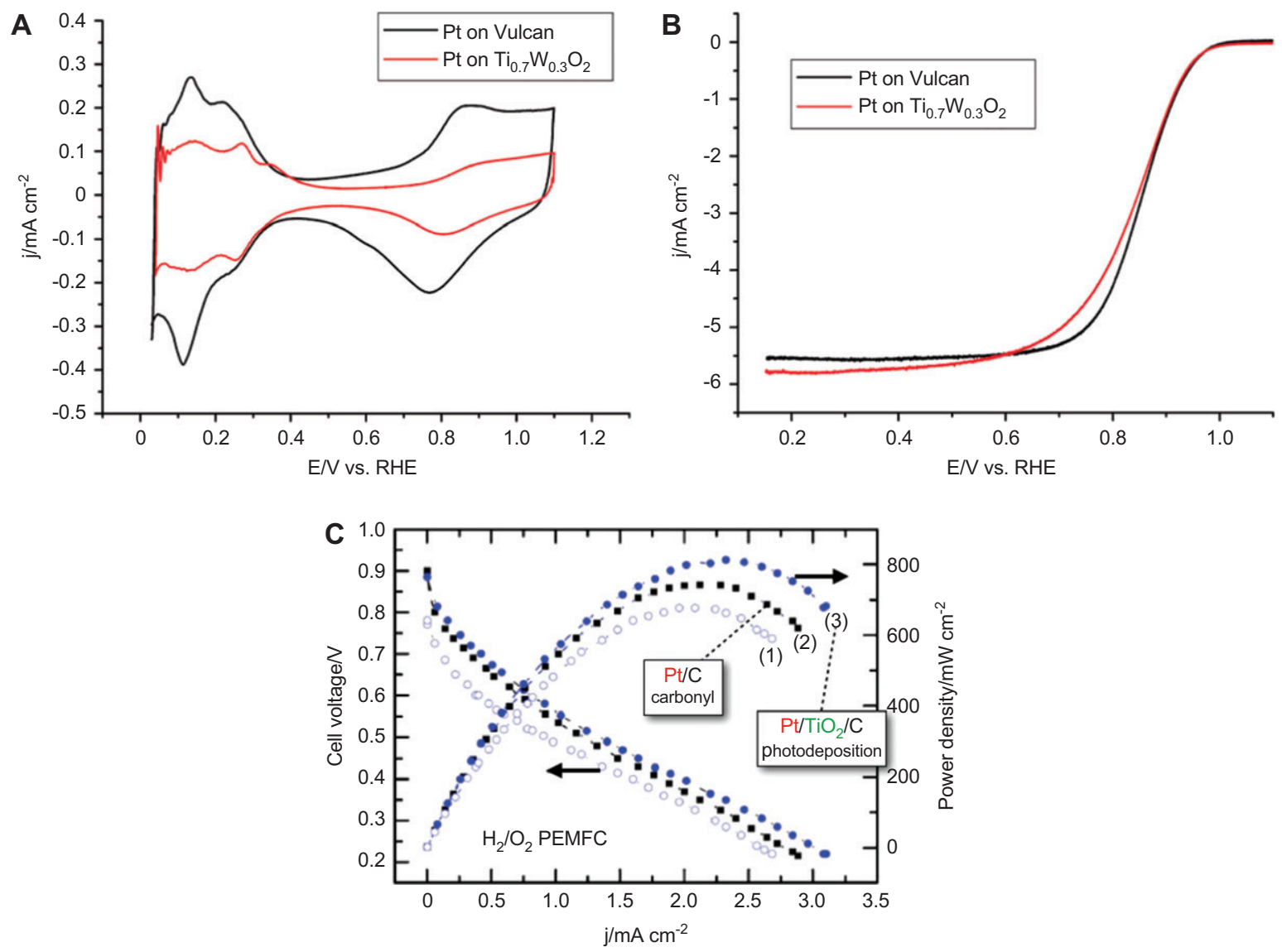

Figure 8 Comparison of $46 \mathrm{wt} \% \mathrm{Pt} / \mathrm{C}$ and $39 \mathrm{wt} \% \mathrm{Ti}_{0.7} \mathrm{~W}_{0.3} \mathrm{O}_{2} / \mathrm{C}$. (A) Cyclic voltammogram and (B) the oxygen reduction reaction (ORR) tested in an oxygen-saturated solution of $0.1 \mathrm{M} \mathrm{H}_{2} \mathrm{SO}_{4}$ using a rotating disk electrode (RDE). Reprinted, with permission, from [122]. Copyright (2010) American Chemical Society. (C) Current potential and power density characteristics of a $\mathrm{H}_{2} / \mathrm{O}_{2}$ PEMFC with the following cathode catalysts: (1) $\mathrm{Pt} / \mathrm{TiO}_{2} / \mathrm{C}, 0.4 \mathrm{mg} \mathrm{cm}{ }^{-2}$, photodeposition; (2) $\mathrm{Pt} / \mathrm{C}, 0.16 \mathrm{mg} \mathrm{cm}^{-2}$, carbonyl; (3) $\mathrm{Pt} / \mathrm{TiO}_{2} / \mathrm{C}, 0.16 \mathrm{mg} \mathrm{cm}^{-2}$, photodeposition. Reprinted with permission from [131]. Copyright (2010) Elsevier. 
substrate for Pt nanoparticles, improve the electrocatalytic activity and tolerance of the metal. Indeed, nanostructured $\mathrm{Pt}$ supported on these composites, i.e., $\mathrm{Pt} / \mathrm{TiO}_{2} / \mathrm{C}$ and $\mathrm{Pt} / \mathrm{WO}_{\mathrm{x}} / \mathrm{C}$, has a higher activity for the ORR than Pt/C alone $[120,148-$ 150].

Furthermore, by using ultraviolet (UV) radiation, it is possible to deposit metallic nanoparticles on $\mathrm{TiO}_{2}-\mathrm{C}$ support [ $[120$, $131,151]$. This method is widely known as photodeposition. To prepare $\mathrm{Pt} / \mathrm{TiO}_{2} / \mathrm{C}$ catalyst, the composite substrate $\mathrm{TiO}_{2} / \mathrm{C}$ is dispersed in argon-saturated water in a photoreactor provided with an optical quartz window. A scheme of the system is shown in Figure 9A. The reaction solution contains isopropanol and $\mathrm{H}_{2} \mathrm{PtCl}_{6} \times 6 \mathrm{H}_{2} \mathrm{O}$. This compound works as a platinum precursor. The solution is kept under stirring for $3 \mathrm{~h}$ and illuminated with a Xenon lamp, which is rich in UV radiation. The electron-hole pairs are photogenerated via UV irradiation on $\mathrm{TiO}_{2}$ present in the substrate composite. Thus, $\left[\mathrm{PtCl}_{6}\right]^{2-}$ is reduced to platinum, $\mathrm{Pt}^{0}$. Generation of the charge carriers is possible because the UV photons have higher energy than the band gap of $\mathrm{TiO}_{2}$ (anatase), which is $3.2 \mathrm{eV}$. The isopropanol molecules serve as sacrificing electron donors. The proposed reaction mechanism is presented in Figure 9B, where it is schematized that the UV-isopropanol excitation channel is also possible. A SMSI takes place and the activity of the metal nanoparticles towards the ORR is enhanced $[119,120]$. Recently, it has been reported that nanoparticles of Pd supported on C-modified by $\mathrm{TiO}_{2}$ (rutile) have higher activity than $\mathrm{Pd} / \mathrm{C}$ for the oxidation of $\mathrm{HCOOH}$ [152].

It is worth noting that deposition of Pt nanoparticles essentially occurs on the $\mathrm{TiO}_{2}$ surface. Enhancement of

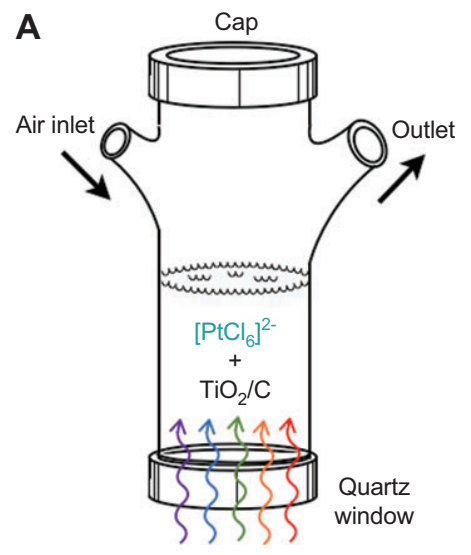

UV+Vis from Xe lamp

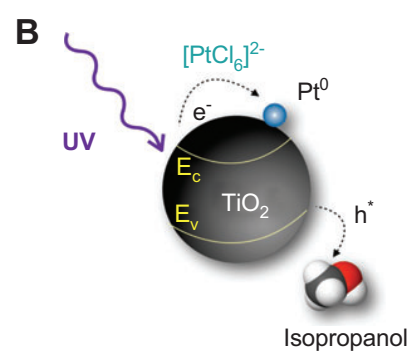

Figure 9 (A) Scheme of the reactor for the synthesis of $\mathrm{Pt} / \mathrm{TiO}_{2} / \mathrm{C}$ by photodeposition. (B) Proposed photoreaction mechanism.
ORR activity in half-cell measurements is reflected by an increase of power density of a single hydrogen/oxygen $\left(\mathrm{H}_{2} /\right.$ $\mathrm{O}_{2}$ ) PEMFC, see Figure 8C. However, improvement in performance is obtained only with low charges of $\mathrm{Pt} / \mathrm{TiO}_{2} / \mathrm{C}$ as mass transport in the composite $\mathrm{TiO}_{2} / \mathrm{C}$ is not as efficient as in $\mathrm{C}$ alone. Finally, tolerance to $\mathrm{CO}[133,139,141,153]$ and $\mathrm{CH}_{3} \mathrm{OH}[131-134,147,154,155]$ poisoning of $\mathrm{Pt}$ supported on the $\mathrm{TiO}_{2}$ is also greatly improved.

4.3.3. Carbon nanotubes Carbon nanotubes (MWCNTs) have been widely studied as a support of electrocatalytic nanoparticles [108, 156-163]. This material has a wide electrochemical potential window, good stability and large surface area [111, 164]. Additionally, the electrocatalytic performance is enhanced [165] due to the enhanced electron transfer characteristics of CNT [166, 167]. Thus, MWCNTs become a promising alternative as a support for electrocatalysts.

4.3.4. Graphene Graphene has extraordinary physical, electronic, optical, mechanical, thermal and chemical properties [168-174]. This novel material has become the most promising support for electrocatalytic [175-177] and photocatalytic [178-181] nanoparticles. Moreover, as corrosion is one of the most critical issues in fuel cells, graphene can be used to prevent corrosion of $\mathrm{Cu}$ and $\mathrm{Ni}$ substrates $[182,183]$.

Nanocrystals of $\mathrm{Co}_{3} \mathrm{O}_{4}$ grown on reduced graphene oxide have been reported as a high performance bifunctional catalyst for the ORR and oxygen evolution reaction (OER) [176]. Furthermore, manganese cobalt spinel $\mathrm{MnCo}_{2} \mathrm{O}_{4}$ /graphene hybrid is an even better electrocatalyst for the ORR in alkaline conditions [184]. The same group from Stanford University has also synthesized $\mathrm{Co}_{1-x} \mathrm{~S} / \mathrm{RGO}$ catalyst [177]. The strong electrochemical coupling of the RGO support with the $\mathrm{Co}_{1-x} \mathrm{~S}$ nanoparticles renders remarkable high ORR catalytic activity and tolerance to methanol. In short, from the viewpoint of the application as a support for nanoparticles for electrochemical energy conversion, graphene may allow to avoid, once and for all, the presence of platinum in the PEMFC.

Concerning the large-scale production of graphene, chemical vapor deposition (CVD) of graphene using $\mathrm{Cu}$ as the catalyst is the most common method for synthesizing single layer of high quality graphene over large areas [185]. Graphene has also been grown by the CVD method on stainless steel substrates $[186,187]$. Rapid progress in terms of large area deposition of thin films via transfer onto plastic and glass substrates has been taking place in the past few years [188, 189]. A large network of universities and corporations such as Samsung and SanDisk are putting great efforts in the mass production of graphene [188-190].

\section{Application of nanoparticles in some electrochemical energy systems}

Increasing global consumption of energy urges to address environmental and technological challenges in the very close 
future [191]. Fuel cells have very low or even zero emission of harmful greenhouse gases such as $\mathrm{CO}_{2}, \mathrm{NO}_{x}, \mathrm{SO}_{x}$, etc. [117]. Therefore, these electrochemical systems are good candidates for solving some of the current environmental issues.

Based on the temperature of operation, there are two types of fuel cells:

- Low temperature fuel cells such as $\mathrm{H}_{2} / \mathrm{O}_{2}$ PEMFC, alkaline fuel cell (AFC), DMFC, microbial or bio-fuel cell and LFFC, etc. The temperature varies depending on the system but the temperature of operation never exceeds $200^{\circ} \mathrm{C}$.

- High temperature fuel cells such as molten carbonate fuel cell (MCFC) and solid oxide fuel cell (SOFC). The temperature of these systems can reach $1000^{\circ} \mathrm{C}$.

The most common elements used in low temperature fuel cells are collected in Table 2. Owing to the large amount of literature on MCFCs and SOFCs, this review will deal solely with low temperature fuel cells, specifically with three of them: $\mathrm{H}_{2} / \mathrm{O}_{2}$ PEMFC, $\mu$ DMFC and LFFC.

\section{1. $\mathrm{H}_{2} / \mathrm{O}_{2}$ PEMFC}

A PEMFC (polymer electrolyte membrane fuel cell) is a low temperature electrochemical energy device that uses hydrogen as fuel and oxygen as oxidant to generate electricity. The PEMFC that uses pure gaseous hydrogen and oxygen (99.999\%) as fuel and oxidant, respectively, has a polymer electrolyte membrane known as $\mathrm{H}_{2} / \mathrm{O}_{2}$ PEMFC. The system that takes the oxygen from air is an air-breathing $\mathrm{H}_{2} / \mathrm{O}_{2}$ PEMFC. A scheme of a $\mathrm{H}_{2} / \mathrm{O}_{2}$ PEMFC (stack) is shown in Figure 10. The $\mathrm{H}_{2}$ and the $\mathrm{O}_{2}$ are delivered to the cathode and anode of the $\mathrm{H}_{2} / \mathrm{O}_{2}$ PEMFC, respectively. The gases are carried and distributed by the bipolar plates. The $\mathrm{H}_{2}$ and $\mathrm{O}_{2}$ diffuse afterwards towards the electrodes through a gas diffusion layer (GDL). The baking layer or current collectors gather the generated electricity. Sometimes this element is omitted if the used GDL is carbon paper. Several layers of micro- and nanostructures comprise the heart of a fuel cell: the membrane electrode assembly (MEA). The MEA is made of one catalyst layer for the anode, the proton exchange membrane and another catalyst layer for the cathode. All the elements of the cathode of the $\mathrm{H}_{2} / \mathrm{O}_{2}$ PEMFC and the ORR process onto $\mathrm{Pt}$ nanoparticles are also schematically represented in Figure 10. The components and usual materials of a $\mathrm{H}_{2} / \mathrm{O}_{2}$ PEMFC are listed in Table 2.

Two electrochemical fuel cell reactions take place at the anode and at the cathode. Thermodynamically, at the anode the hydrogen oxidation occurs according to [192]:

$\mathrm{H}_{2} \rightarrow 2 \mathrm{H}^{+}+2 \mathrm{e}^{-} \quad E^{\circ}=0 \mathrm{~V}$

The protons $\mathrm{H}^{+}$are exchanged through a humidified polymer electrolyte membrane (PEM), which is usually Nafion ${ }^{\circledast}$, developed by DuPont. At the cathode, the oxygen reduces to produce water:

$1 / 2 \mathrm{O}_{2}+2 \mathrm{H}^{+}+2 \mathrm{e}^{-} \rightarrow 2 \mathrm{H}_{2} \mathrm{O} \quad E^{\circ}=1.229 \mathrm{~V}$

The water flows out through the cathode GDL and is carried out the cell along the flow channels of the bipolar plates. The overall electrochemical reaction in a single $\mathrm{H}_{2} / \mathrm{O}_{2}$ PEMFC is expected to deliver a cell voltage of $1.229 \mathrm{~V}$.

$\mathrm{H}_{2}+1 / 2 \mathrm{O}_{2} \rightarrow \mathrm{H}_{2} \mathrm{O}$

Table 2 Usual components of hydrogen/oxygen polymer electrolyte fuel cell $\left(\mathrm{H}_{2} / \mathrm{O}_{2}\right.$ PEMFC), micro-direct methanol fuel cell ( $\mu$ DMFC) and a laminar flow fuel cell (LFFC).

\begin{tabular}{|c|c|c|c|c|}
\hline \multicolumn{2}{|c|}{$\begin{array}{l}\text { Low temperature fuel cell } \\
\text { components }\end{array}$} & \multirow{2}{*}{$\begin{array}{l}\mathrm{H}_{2} / \mathrm{O}_{2} \text { PEMFC } \\
\text { Nafion }^{\circledR} 112 \text { or } 115\end{array}$} & \multirow{2}{*}{$\begin{array}{l}\mu \text { DMFC } \\
\text { Nafion }^{\circledR} 212\end{array}$} & \multirow{2}{*}{$\begin{array}{l}\text { LFFC } \\
\text { Liquid: acid or alkaline }\end{array}$} \\
\hline Electrolyte & & & & \\
\hline \multirow[t]{5}{*}{ Anode } & Catalyst, charge & $\mathrm{Pt}, 0.2 \mathrm{mg} \mathrm{cm}^{-2}$ & $\mathrm{Pt}-\mathrm{Ru}(50: 50), 4 \mathrm{mg} \mathrm{cm}^{-2}$ & $\begin{array}{l}\text { Depending on the fuel: black } \\
\text { nanoparticles, } 10 \mathrm{mg} \mathrm{cm}^{-2}\end{array}$ \\
\hline & Catalyst support & Carbon black & Carbon black or carbon nanotubes & Graphite or Toray paper \\
\hline & Ionomer & $\begin{array}{l}\text { Nafion }^{\circledast} \text { from a mixture of lower } \\
\text { aliphatic alcohols and water }\end{array}$ & $\begin{array}{l}\text { Nafion }{ }^{\circledast} \text { from a mixture of lower } \\
\text { aliphatic alcohols and water }\end{array}$ & $\begin{array}{l}\text { Nafion }{ }^{\circledast} \text { from a mixture of lower } \\
\text { aliphatic alcohols and water }\end{array}$ \\
\hline & Microporous layer & $\begin{array}{l}\text { Carbon black + hydrophobic } \\
\text { agent (PTFE) }\end{array}$ & $\begin{array}{l}\text { Carbon black + hydrophobic } \\
\text { agent (PTFE) }\end{array}$ & NA \\
\hline & $\begin{array}{l}\text { Macroporous layer } \\
\text { (GDL) }\end{array}$ & Carbon cloth or Toray paper & $\begin{array}{l}\text { Carbon paper or metallic } \\
\text { mesh/felt }\end{array}$ & $\mathrm{NA}^{1}$ \\
\hline \multirow[t]{5}{*}{ Cathode } & Catalyst, charge & $\mathrm{Pt}, 0.2 \mathrm{mg} \mathrm{cm}^{-2}$ & $\mathrm{Pt}, 4 \mathrm{mg} \mathrm{cm}^{-2}$ & $\mathrm{Pt}, 2 \mathrm{mg} \mathrm{cm}^{-2}$ \\
\hline & Catalyst support & Carbon black & Carbon black & Carbon black \\
\hline & Ionomer & $\begin{array}{l}\text { Nafion }{ }^{\circledR} \text { from a mixture of lower } \\
\text { aliphatic alcohols and water }\end{array}$ & $\begin{array}{l}\text { Nafion }{ }^{\circledR} \text { from a mixture of lower } \\
\text { aliphatic alcohols and water }\end{array}$ & $\begin{array}{l}\text { Nafion }^{\circledR} \text { from a mixture of lower } \\
\text { aliphatic alcohols and water }\end{array}$ \\
\hline & Microporous layer & $\begin{array}{l}\text { Carbon black }+ \text { hydrophobic } \\
\text { agent (PTFE) }\end{array}$ & $\begin{array}{l}\text { Carbon black + hydrophobic } \\
\text { agent (PTFE) }\end{array}$ & NA \\
\hline & $\begin{array}{l}\text { Macroporous layer } \\
\text { (GDL) }\end{array}$ & Carbon cloth or Toray paper & Toray paper & Toray paper \\
\hline $\begin{array}{l}\text { Electrode } \\
\text { holder }^{2}\end{array}$ & & $\begin{array}{l}\text { Graphite composite, coated } \\
\text { stainless steel }\end{array}$ & $\begin{array}{l}\text { Silicon, graphite composite, } \\
\text { stainless steel or a plastic }\end{array}$ & $\begin{array}{l}\text { Graphite, stainless steel or } \\
\text { plastic case }\end{array}$ \\
\hline
\end{tabular}

${ }^{1}$ Not applicable. ${ }^{2}$ In the case of a stack, this component is called "Bipolar plate". 


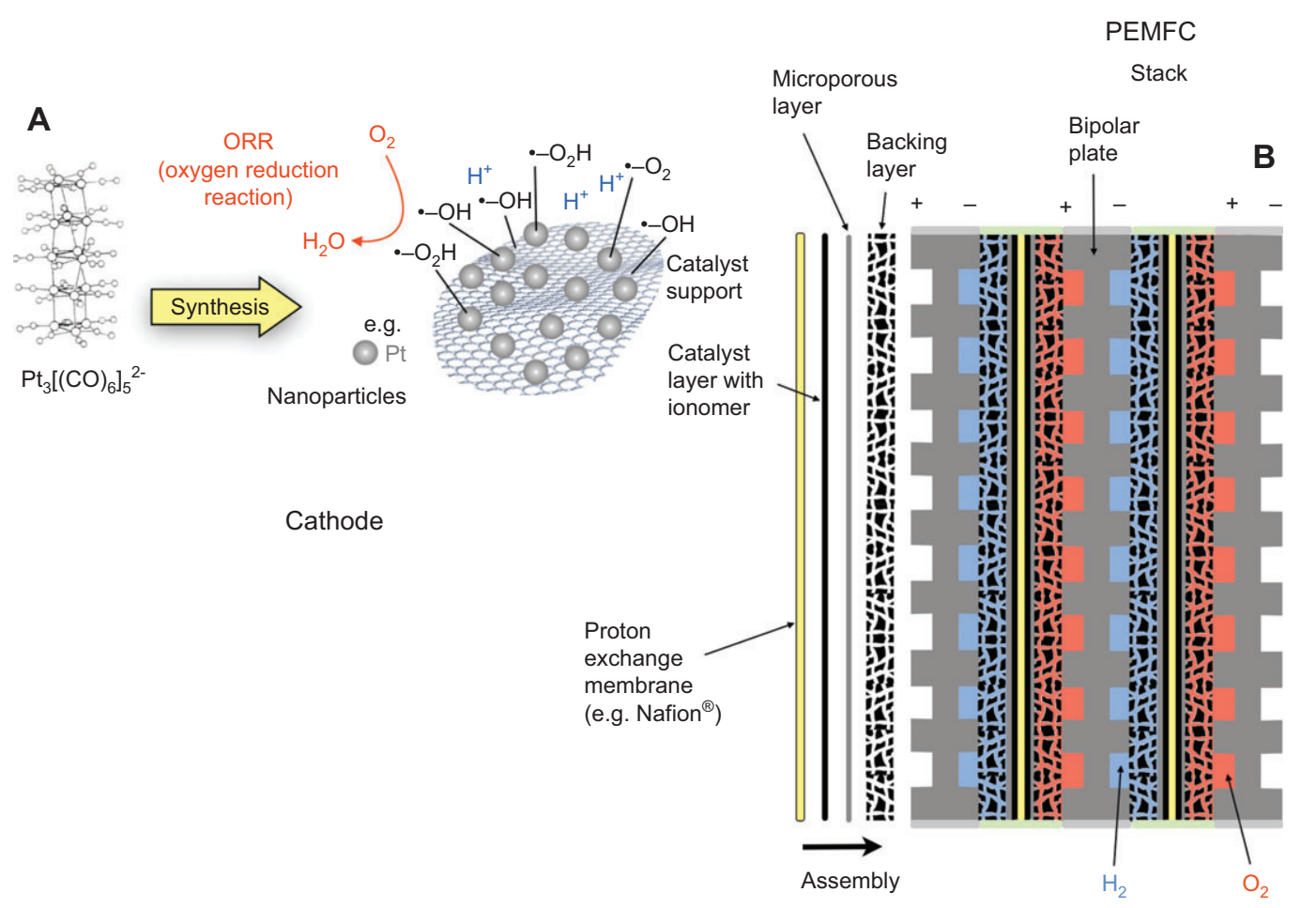

Figure 10 (A) Scheme of a hydrogen/oxygen polymer electrolyte fuel cell $\left(\mathrm{H}_{2} / \mathrm{O}_{2}\right.$ PEMFC) stack and its components: polymer membrane, catalyst, microporous and gas diffusion layer (GDL). (B) The bipolar plates are also shown.

It is worth noting that the performance of a single cell alone cannot be employed to predict the performance of a stack due to the coupling of stack size with heat and mass transfer [193, 194].

The $\mathrm{H}_{2} / \mathrm{O}_{2}$ PEMFC is mostly used in vehicles for transportation purposes. Several fuel cell vehicles (FCVs) such as GM Hydrogen 1, XTERRA FCV, Toyota FCHV, Honda FCX clarity, etc., are already being tested. This later vehicle is offered for $\$ 600$ per month (3-year lease) to selected customers (http://automobiles.honda.com/fcx-clarity/). Most of the fuel cell automobiles are being tested in California as it has the most developed infrastructure for $\mathrm{H}_{2}$ fueling.

Several reviews about PEMFC technology are continuously written every year. One of the most recent ones is a review by Wang et al. on technology, applications and needs on fundamental research of PEMFC [195]. There are other compilations about the use of PEMFC FCVs [196] long-term stability and degradation [113,121, 197-200], precious and non-precious catalysts [201-206], support for catalysts [117], GDLs [207], current collectors, bipolar plates [168, 208], stack manufacturing and testing [209, 210], etc.

To date, the two main barriers to overcome commercialization of the $\mathrm{H}_{2} / \mathrm{O}_{2}$ PEMFC are [195]:

- Cost: the U.S. Department of Energy (DOE) target is to reduce the cost of manufacture from $\$ 45$ (2010) to $\$ 30 \mathrm{~kW}^{-1}$ (2015) for transportation applications.

- Durability: most fuel cells exhibit an important decay in performance after $1000 \mathrm{~h}$ of operation. This lifetime is far from being acceptable, because according to the DOE target for 2015 it should last $5000 \mathrm{~h}$ with $60 \%$ efficiency for transportation.

The most common nanoparticle catalyst used as an electrode for a $\mathrm{H}_{2} / \mathrm{O}_{2}$ PEMFC is platinum. According to the target of DOE for 2015, the amount of Pt should be $0.2 \mathrm{mg} \mathrm{cm}^{-2}$ with a corresponding volumetric performance of $650 \mathrm{~W} \mathrm{l}^{-1}$. The scarcity of Pt and its high cost have led to the development of alternative Pt-free catalysts for fuel cell applications [202-204]. Figure 11 shows the time evolution and status of costs of the PEMFC components, as well as what is expected for 2015 .

The other major obstacle of the $\mathrm{H}_{2} / \mathrm{O}_{2}$ PEMFC being accepted as a commercially viable product is durability [113, 197]. Practically all the components of the PEMFC, bipolar plates, GDL, Pt-free catalysts, catalyst support and membrane, are not stable for long periods. Table 3 presents degradation causes of the components of a $\mathrm{H}_{2} / \mathrm{O}_{2}$ PEMFC. A solution, which is still under development, for durability issues is also given in the third column of Table 3. Apart from structural, mechanical, thermal and other technical issues such as the $\mathrm{CO}$ (present in ppm in $\mathrm{H}_{2}$ ) poisoning of $\mathrm{Pt}$, corrosion is the greatest challenge to address. Additionally, electrode flooding is a critical issue that affects operation of a fuel cell for long periods.

Durability issues concern the components of MEA [113, 197-200, 212]. Degradation mainly occurs during the startup and shutdown processes [121]. By contrast, the 


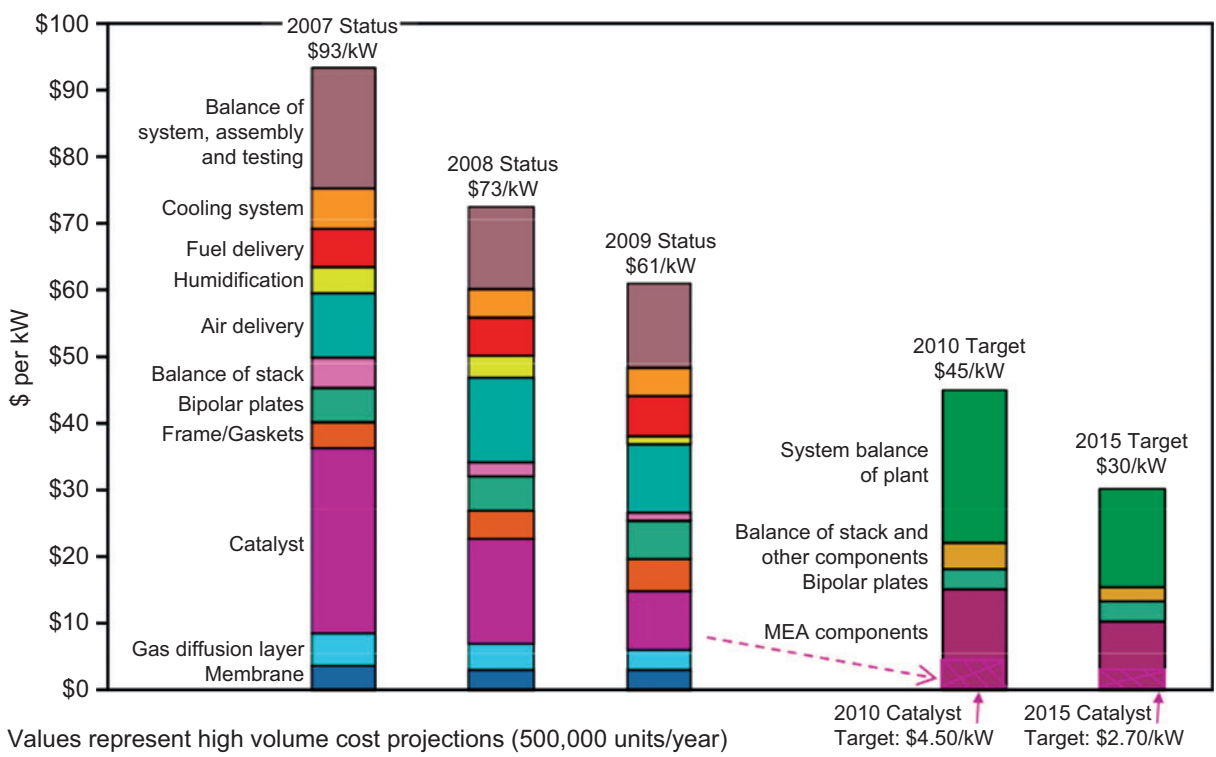

Figure 11 Current status of the costs of the components of a hydrogen/oxygen polymer electrolyte fuel cell $\left(\mathrm{H}_{2} / \mathrm{O}_{2} \mathrm{PEMFC}\right)[211]$.

Nafion ${ }^{\circledR}$ membrane is poisoned by metal anions from corrosion of metallic bipolar plates. Bipolar plates are key components of the $\mathrm{H}_{2} / \mathrm{O}_{2}$ PEMFC as they account for significant fractions of their weight and cost. Metallic materials have advantages over graphite-based bipolar plates, due to higher mechanical strength and better electrical conductivity. However, corrosion resistance is a major concern that remains to be solved as metals may develop oxide layers that increase electrical resistivity, thus lowering fuel cell efficiency [208, 213].

\subsection{Micro-DMFC}

DMFC is a low temperature electrochemical energy device that uses methanol as fuel and oxygen as oxidant to generate electricity. The system uses methanol directly, i.e., without

Table 3 Degradation of components of a hydrogen/oxygen polymer electrolyte fuel cell $\left(\mathrm{H}_{2} / \mathrm{O}_{2}\right.$ PEMFC).

\begin{tabular}{|c|c|c|}
\hline $\begin{array}{l}\text { Component of } \mathrm{H}_{2} / \mathrm{O}_{2} \\
\text { PEMFC }\end{array}$ & Degradation & Solution under research \\
\hline Anode catalyst & $\begin{array}{l}\text { - Poisoning with impurities of } \mathrm{CO}, \mathrm{H}_{2} \mathrm{~S}, \mathrm{SO}_{\mathrm{x}} \text {, } \\
\mathrm{NO}_{\mathrm{x}}, \mathrm{HCN} \text { present in } \mathrm{H}_{2}\end{array}$ & $\begin{array}{l}\text { - Tolerant anode catalysts such as Pt-M (M = Co, } \\
\text { Sn, } \mathrm{Cr}, \mathrm{Ru}) \\
\text { - Use } \mathrm{H}_{2} \text { produced from PEM electrolysis or } \\
\text { natural sources }\end{array}$ \\
\hline Cathode catalyst and & - Dissolution under non-equilibrium conditions & \\
\hline support & $\begin{array}{l}\text { - Corrosion of carbon Vulcan XC-72 during start/ } \\
\text { stop cycling, particle grow and consequently } \\
\text { loss of electrochemical surface area (ESA) }\end{array}$ & $\begin{array}{l}\text { - Use alternative catalysts supports such as } \\
\text { MWCNT, graphene, oxides and carbides }\end{array}$ \\
\hline Membrane & $\begin{array}{l}\text { - Creep, microcrack fractures } \\
\text { - Structural and morphological changes } \\
\text { - Crossover leak } \\
\text { - Internal resistance increases } \\
\text { - Corrosion from } \mathrm{H}_{2} \mathrm{O}_{2} \\
\text { - Anion poisoning } \\
\text { - Pt diffuses into the membrane }\end{array}$ & $\begin{array}{l}\text { - Use novel membranes with improved physical } \\
\text { and chemical properties } \\
\text { - Use carbon composite bipolar plates or coated } \\
\text { stainless steel } \\
\text { - Use novel supports }\end{array}$ \\
\hline $\begin{array}{l}\text { Gas diffusion layer } \\
\text { (GDL) and interconnects }\end{array}$ & $\begin{array}{l}\text { - } \mathrm{H}_{2} \mathrm{O} \text { flooding } \\
\text { - Hydrophobicity loss } \\
\text { - Decrease in the mass transport properties }\end{array}$ & $\begin{array}{l}\text { - Use novel carbon paper GDL } \\
\text { - Increase the content of Teflon solution } \\
\text { - Use novel metal sinter, felt or mesh as current } \\
\text { collector }\end{array}$ \\
\hline $\begin{array}{l}\text { Metal or graphite bipolar } \\
\text { plates }\end{array}$ & $\begin{array}{l}\text { - Metal: corrosion produces metal cations, which } \\
\text { poison the MEA } \\
\text { - Graphite: loss of mechanical strength }\end{array}$ & $\begin{array}{l}\text { - Use conductive corrosion-resistant coatings } \\
\text { - Use composite bipolar plates with high } \\
\text { conductivity }\end{array}$ \\
\hline
\end{tabular}


being reformed. Basically, the DMFC has the same components as that of a $\mathrm{H}_{2} / \mathrm{O}_{2}$ PEMFC, but the materials used are different, especially for the anode (see fourth column of Table 2).

The working principle of a DMFC can be described as follows. As for $\mathrm{H}_{2} / \mathrm{O}_{2}$ PEMFC, two electrochemical reactions also take place in the electrodes of the DMFC. At the anode, methanol is catalytically oxidized, without previous reformation, according to [192]:

$$
\mathrm{CH}_{3} \mathrm{OH}+\mathrm{H}_{2} \mathrm{O} \rightarrow 6 \mathrm{H}^{+}+6 \mathrm{e}^{-}+\mathrm{CO}_{2} \uparrow \quad E^{\circ}=0.02 \mathrm{~V}
$$

The protons $\mathrm{H}^{+}$are exchanged in the electrolyte, a wet PEM which usually is Nafion ${ }^{\oplus}$. At the cathode, the oxygen is catalytically reduced to produce water:

$$
3 / 2 \mathrm{O}_{2}+6 \mathrm{H}^{+}+6 \mathrm{e}^{-} \rightarrow 3 \mathrm{H}_{2} \mathrm{O} \quad E^{\circ}=1.23 \mathrm{~V}
$$

Therefore, the overall electrochemical reaction in a single DMFC is:

$$
\mathrm{CH}_{3} \mathrm{OH}+3 / 2 \mathrm{O}_{2} \rightarrow \mathrm{CO}_{2}+\mathrm{H}_{2} \mathrm{O} \quad E^{\circ}=1.21 \mathrm{~V}
$$

Initially, DMFCs were intended for transportation purposes. However, application of these systems in portable devices is what has motivated an increasing focus on research and development. Hence, the dimensions of the DMFC have been greatly reduced until having a $\mu \mathrm{DMFC}$. Figure $12 \mathrm{~A}$ shows an example of a $\mu \mathrm{DMFC}$ with current collectors made
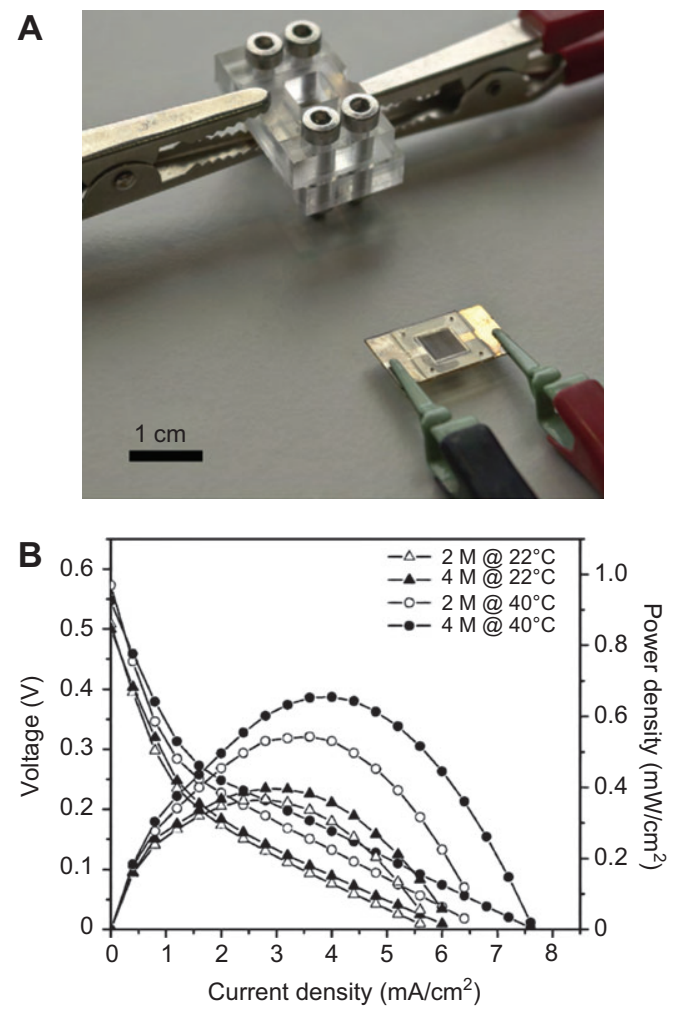

Figure 12 Micro-direct methanol fuel cell with current collectors made of Si and SU-8. Reprinted, with permission, from [214]. Copyright (2010) Elsevier. of SU-8, which is a typical material used in the fabrication of micro-electromechanical systems (MEMS). Figure 12B presents the current potential characteristics of the device operating at different temperatures and with different concentrations of methanol. The $\mu \mathrm{DMFC}$ are in most cases airbreathing. The $\mu$ DMFC have already been used in portable electronic devices [215-219], cell phones [220] and robots [221]. Several reviews concerning $\mu$ DMFC technology, challenges and technical issues have been published [222, 223].

Commercialization of passive $\mu \mathrm{DMFCs}$ is still hindered by a number of difficulties, namely, high cost, low activity and selectivity of the catalysts [224, 225], water management [226], fuel crossover [227-233] through the PEM and of course the microfabrication itself $[215,223]$. One of the most critical issues in $\mu \mathrm{DMFC}$ is the limitation of using highly concentrated methanol [234]. Usually, the $\mu \mathrm{DMFC}$ has to use fuel at $4 \mathrm{M}$, thus power pack density decreases and consequently their chances to efficiently power portable electronics is reduced [234]. To overcome the issue of fuel crossover, a thicker membrane has to be used [235] or its properties have to be modified [236].

\subsection{Laminar flow fuel cells}

In the past decade, an alternative to $\mu \mathrm{DMFC}$ for powering portable devices has attracted the interest of the research community. It is the so-called microfluidic fuel cell [237, 238]. Several reviews and book chapters have been written about this power source [239-242]. The microfluidic fuel cell was developed for the first time in Harvard by Whitesides and coworkers [243]. Figure 13A shows a scheme of the first microfluidic fuel cell. This system was of the type " $Y$ " and used the redox couple $\mathrm{VO}_{2}{ }^{+} / \mathrm{VO}^{2+}$ to generate electricity. More details of the working principle of microfluidic fuel cells will be given in the following paragraphs. The Kenis group and the company INI Power Systems have made remarkable improvements to the fuel cell system [237, 238, 245-260]. Additionally, microfluidic fuel cells have been widely studied from a modeling approach $[238,261,262]$. More recently, the Kjeang group [239, 241, 242, 263], the Alonso-Vante group [131, 264-266], the H. Wang group [263, 267, 268] and the C. Wang group [269] have also contributed significantly to the development of microfluidic fuel cells.

The microfluidic fuel cell is also widely known as laminar (LFFC) [237, 259]. In a recent work we have named it membraneless micro fuel cell, because the major characteristics include lack of a polymer membrane and microfabricated components. The lack of a polymer membrane allows the LFFC to use a large variety of fuels [256] including hydrogen [247, 253], methanol [246, 248, 251, 255], ethanol [260], formic acid [131, 264, 265], sodium borohydride, hydrazine $[250,260]$ and glucose [270]. Table 4 lists various examples of LFFCs with different fuels, electrolytes (acid or basic medium) and the generated power densities. Indeed, LFFCs have very promising capabilities to solve many of the technical difficulties currently present in $\mu \mathrm{DMFC}[239,240]$.

The working principle of the microfluidic fuel cell is based on the science of microfluidics of laminar flows. The laminar 

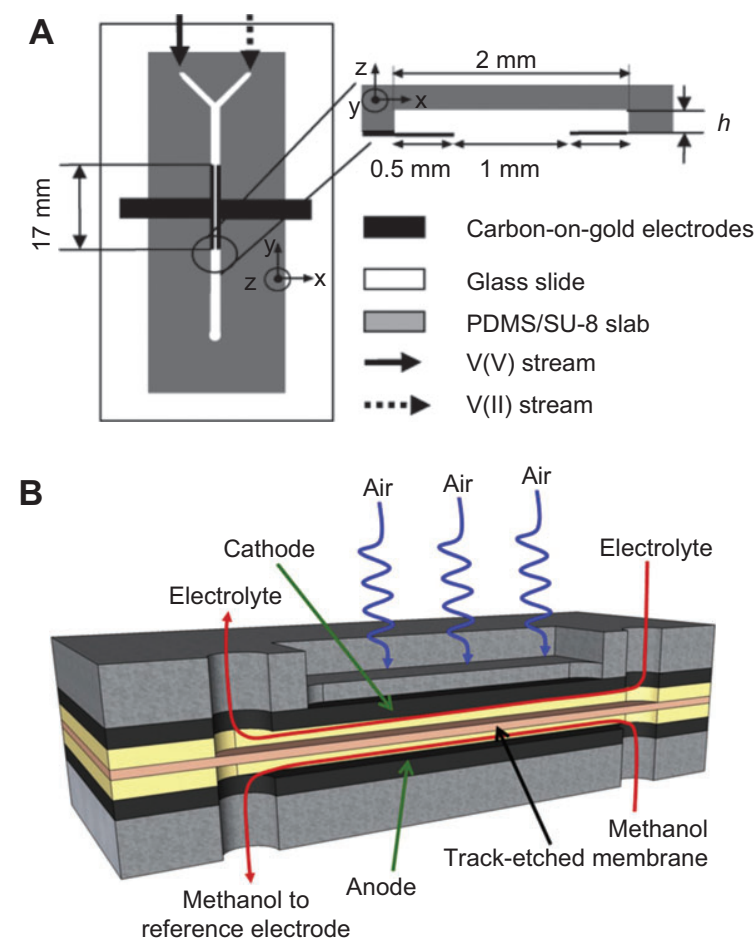

Figure 13 (A) First microfluidic fuel cell, type "Y", with Au electrodes and $\mathrm{VO}_{2}{ }^{+} / \mathrm{VO}^{2+}$ redox couple. As electrolyte $0.5 \mathrm{M} \mathrm{H}_{2} \mathrm{SO}_{4}$ was used. Reprinted, with permission, from [243]. Copyright (2002) American Chemical Society. (B) Laminar flow fuel cell (LFFC) with an air-breathing cathode and nanoporous separator between the anolythe (anode stream) and catholyte (cathode stream). Reprinted, with permission, from [244]. Copyright (2012) Elsevier.

flows are streams in which the components flow in parallel without being mixed. The nature of the fluid depends on the number of Reynolds, which characterizes the inertial forces with respect to viscosity:

$\operatorname{Re}=\frac{\rho U D_{h}}{\mu}$ where $\rho$, the volumetric mass or density of the fluid, is in $\mathrm{kg}$ $\mathrm{m}^{-3} ; U$ is the average flow speed in $\mathrm{m} \mathrm{s}^{-1} ; D_{h}$, the hydraulic diameter, is in $\mathrm{m} ; \mu$, the kinematic viscosity, is in $\mathrm{m}^{2} \mathrm{~s}^{-1}$.

Additionally, the number of Péclet characterizes the nature of mass transport. This number represents the ratio between the transfer by convection and the transfer by diffusion:

$P e=\frac{U D_{h}}{D}$

with $D$, the coefficient of diffusion, in $\mathrm{m}^{2} \mathrm{~s}^{-1}$. A flow with number of Reynolds of $<2000$ will have a laminar regime. In this case, the lines of flow current are parallel and well defined.

The velocity of a particle of the fluid can be calculated according to the Navier-Stokes equation:

$\rho\left(\frac{\partial \vec{u}}{\partial t}+\vec{u} \cdot \nabla \vec{u}\right)=-\nabla p+u \nabla^{2} \vec{u}+\vec{f}$

where $p$ is pressure, $u$ is velocity of a particle of the fluid, $t$ is temporal and parameter $f$ is body forces per unit of volume. In particular, Eq. (21) allows the description and prediction of the motion of the fluids at the microscale, i.e., microfluidics. In general, the instabilities in a fluid are directly associated with the non-linear term $(u+\nabla u)$, which represents the inertial mass transport by convection. Moreover, for an incompressible fluid with constant density, the conservation of mass follows the equation of continuity:

$\left(\frac{\partial \rho}{\partial t}+\nabla \cdot(\rho \vec{u})\right)=0$

The motion of the fluid, resulting from solving Eq. (21) with Eq. (22) and Eq. (19), has a parabolic, flat and uniform profile of flow speed. Thus, the streams that flow through a channel of micrometric dimensions $\left(D_{h}<1000 \mu \mathrm{m}\right)$ behave differently to those that flow in the domestic pipelines or hurricanes. Summarizing, at a micrometric level, there are no

Table 4 Laminar flow fuel cells (LFFCs) with different fuels, oxidants, electrolytes and electrocatalysts.

\begin{tabular}{|c|c|c|c|c|c|}
\hline $\begin{array}{l}\text { LFFC fuel/ } \\
\text { oxidant }\end{array}$ & Electrolyte & $\begin{array}{l}\text { Anode catalyst/synthesis method } \\
\text { or provider }\end{array}$ & $\begin{array}{l}\text { Cathode catalyst/synthesis method } \\
\text { or provider }\end{array}$ & $\begin{array}{l}\text { Maximum power } \\
\text { density } / \mathrm{mW} \mathrm{cm}^{-2}\end{array}$ & References \\
\hline $\mathrm{H}_{2} / \mathrm{O}_{2}$ & $\mathrm{H}_{2} \mathrm{SO}_{4}$ & Pt black, $3 \mathrm{mg} \mathrm{cm}^{-2} /$ Alfa Aesar & Pt black, $3 \mathrm{mg} \mathrm{cm}^{-2} /$ Alfa Aesar & 191 & [253] \\
\hline $\mathrm{VO}_{2}^{++} / \mathrm{VO}^{2+}$ & $\mathrm{H}_{2}^{2} \mathrm{SO}_{4}$ & Carbon-on-gold/PVD & Carbon-on-gold/PVD & 192 & [243] \\
\hline $\mathrm{HCOOH} / \mathrm{air}$ & $\mathrm{H}_{2} \mathrm{SO}_{4}$ & Pd black, $10 \mathrm{mg} \mathrm{cm}^{-2} /$ Alfa Aesar & $\begin{array}{l}10 \mathrm{wt} \% \mathrm{Pt} / \mathrm{C}, 0.35 \mathrm{mg} \mathrm{cm}^{-2}+\mathrm{Pt} \\
\text { black, } 2 \mathrm{mg} \mathrm{cm}^{-2} / \mathrm{E}-\mathrm{TEK}\end{array}$ & 26 & [237] \\
\hline $\mathrm{HCOOH} / \mathrm{O}_{2}$ & $\mathrm{H}_{2} \mathrm{SO}_{4}$ & $30 \mathrm{wt} \% \mathrm{Pd} / \mathrm{C}, 2 \mathrm{mg} \mathrm{cm}^{-2} / \mathrm{E}-\mathrm{TEK}$ & $8 \mathrm{wt} \% \mathrm{Pt} / \mathrm{C}, 0.8 \mathrm{mg} \mathrm{cm}^{-2} /$ carbonyl & 17.1 & This work \\
\hline $\mathrm{MeOH} /$ air & $\mathrm{H}_{2} \mathrm{SO}_{4}$ & $\begin{array}{l}\text { Pt-Ru (50:50) black, } 10 \mathrm{mg} \mathrm{cm}^{-2} / \\
\text { Alfa Aesar }\end{array}$ & $\begin{array}{l}10 \mathrm{wt} \% \mathrm{Pt} / \mathrm{C}, 0.35 \mathrm{mg} \mathrm{cm}^{-2}+\mathrm{Pt} \\
\text { black, } 2 \mathrm{mg} \mathrm{cm}^{-2} / \mathrm{E}-\mathrm{TEK}\end{array}$ & 11.8 & {$[255]$} \\
\hline $\mathrm{MeOH} / \mathrm{air}$ & $\mathrm{KOH}$ & $\begin{array}{l}\text { Pt-Ru (50:50) black, } 10 \mathrm{mg} \mathrm{cm}^{-2} / \\
\text { Alfa Aesar }\end{array}$ & $\begin{array}{l}10 \mathrm{wt} \% \mathrm{Pt} / \mathrm{C}, 0.35 \mathrm{mg} \mathrm{cm}^{-2}+\mathrm{Pt} \\
\text { black, } 2 \mathrm{mg} \mathrm{cm}^{-2} / \mathrm{E}-\mathrm{TEK}\end{array}$ & 17.2 & {$[255]$} \\
\hline EtOH/air & $\mathrm{KOH}$ & $\mathrm{Pt} / \mathrm{Ru}$ black, $10 \mathrm{mg} \mathrm{cm}^{-2} / \mathrm{NR}$ & Pt black, $2 \mathrm{mg} \mathrm{cm}^{-2} / \mathrm{E}-\mathrm{TEK}$ & 7.2 & {$[260]$} \\
\hline Hydrazine & $\mathrm{KOH}$ & $\mathrm{Pt}, 10 \mathrm{mg} \mathrm{cm}^{-2} / \mathrm{NR}$ & NR & 80 & {$[260]$} \\
\hline $\mathrm{NaBH}_{4}$ & $\mathrm{KOH}$ & Pt black, $10 \mathrm{mg} \mathrm{cm}^{-2} / \mathrm{E}-\mathrm{TEK}$ & Pt black, $2 \mathrm{mg} \mathrm{cm}^{-2} / \mathrm{E}-\mathrm{TEK}$ & 101 & {$[250,260]$} \\
\hline Glucose $/ \mathrm{O}_{2}$ & $\mathrm{Fe}(\mathrm{CN})_{6}^{3-}$ & Gold/sputtering & Gold/sputtering & 0.11 & {$[270]$} \\
\hline
\end{tabular}

The electrodes, anode and cathode, and maximum power density achieved are also indicated. 
turbulences. This laminar regime of the fluids can be used to replace the physical polymer membrane of the fuel cells such as $\mathrm{H}_{2} / \mathrm{O}_{2}$ PEMFC or $\mu$ DMFC.

Reactants of the electrochemical energy device, i.e., fuel and oxidant, are carried without mixing two streams that flow in parallel along a microchannel. Thus, the stream containing the oxidant $\left(\mathrm{O}_{2}\right)$ flows on top of the cathode. This is called the catholyte. The system is called air-breathing LFFC when it takes the oxygen directly from air [237]. Figure 13B schematizes an air-breathing LFFC. The stream containing the fuel $\left(\mathrm{CH}_{3} \mathrm{OH}, \mathrm{CH}_{3} \mathrm{CH}_{2} \mathrm{OH}, \mathrm{HCOOH}\right.$, glucose, etc.) flows on top of the anode and it is called the anolythe. The protons diffuse through the liquid interface (diffuse mixing) [239, 253, 263] between these two laminar flows. Thus, a microfluidic or laminar flow fuel cell without a physical membrane is conceived.

However, as for $\mu$ DMFCs, the phenomenon of fuel crossover when high concentrated fuel is used also occurs with LFFCs. The fuel gradually crosses from the catholyte to the anolythe through the diffusive mixing region. The width of this diffusive mixing region can be calculated according to the expression [239]:

$\Delta x \approx\left(\frac{D h y}{U}\right)^{1 / 3}$

where $h$ is the channel height, $y$ is the distance the fluid flows downstream, and $U$ is the average flow speed.

A mixed potential, resulting from the simultaneous oxidation of the fuel and the reduction of molecular oxygen (ORR) at the cathode, is produced. The mixed potential reduces the overall performance of the LFFC. The fuel crossover can be reduced increasing the flow speed of the catholyte [239] or using a nanoporous separator placed between the streams [246, 251], see Figure 13B. The nanoporous separator reduces the gradient of diffusion of fuel but increases the internal resistance of the LFFC. The negative effect becomes more evident when using a micro-pump to recycle the reactants. The fluids are recycled, as it is not expected that neither the electrolyte nor the unreacted fuel is going to be wasted.

Additionally, the reduction of the dimensions of the LFFC is highly restricted [229, 238]. Sprague et al. have shown that when fueling $(0.1 \mathrm{M})$ a LFFC with a single-channel $50 \mu \mathrm{m}$ wide, the two streams become completely mixed (100\% fuel crossover) after $5 \mathrm{~mm}$ of distance from the inlet [229]. When increasing the length of the microchannel and reducing the width, a negative effect of the fuel crossover becomes even worse [229, 238, 261]. To overcome the detrimental effect of fuel crossover that occurs at the interface of the anolythe and the catholyte, tolerant chalcogenide catalyst such as $\mathrm{CoSe}_{2}$ [271, 272], $\mathrm{Pt}_{\mathrm{x}} \mathrm{Se}_{\mathrm{y}}$ [273], $\mathrm{Pt}_{\mathrm{x}} \mathrm{S}_{\mathrm{y}}$ [274] and $\mathrm{Ru}_{\mathrm{x}} \mathrm{Se}_{\mathrm{y}}$ [275-277] can be used to carry out the ORR. Recently, these catalysts have been used as cathodes [248, 264-266] of microfluidic fuel cells, showing that they can indeed avoid the production of the mixed potential at high concentrations of fuel.

The performance of the LFFC depends on the orientation and position of the cell $[257,268]$. The gravity effects on these systems have been studied through a coupled computational fluid dynamics (CFD)/electrochemical model [268]. Airbreathing reversible microfluidic fuel cells (RMFC) have the flexibility that they can be used as membraneless electrolysers in either acid or alkaline medium when having a bifunctional oxygen electrode [267].

Figure 14A depicts a link between the previous and the present sections. It presents the current potential and power density characteristics of a LFFC that uses formic acid as fuel and Pt nanoparticles supported on carbon substrate as cathode. The long chain of events that were conducted for measurements presented in Figure 14A are listed as follows:

- Synthesis of the carbonyl precursor: $\left[\mathrm{Pt}_{3}(\mathrm{CO})_{6}\right]_{5}{ }^{2-}[48]$.

- Nucleation and growth of Pt nanoparticles onto carbon Vulcan XC-72 [91].
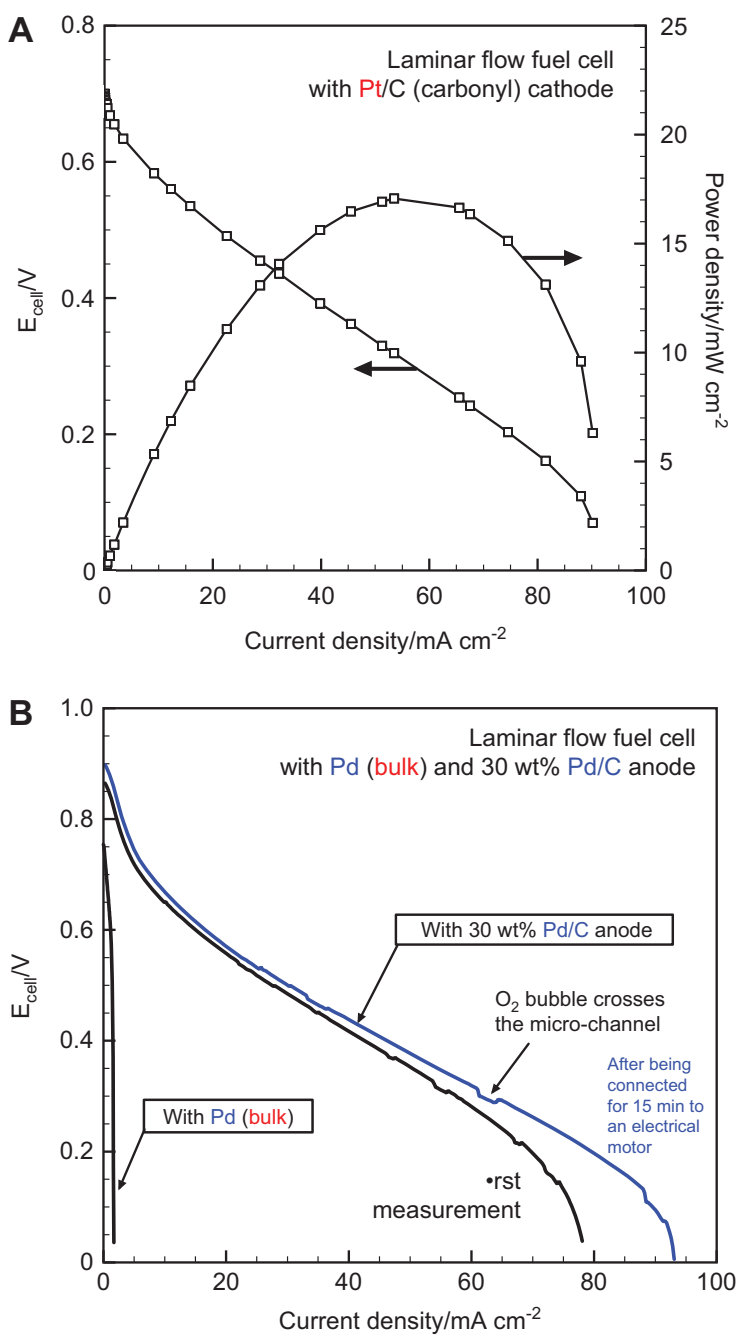

Figure 14 (A) Polarization and power density curves for $8 \mathrm{wt} \%$ $\mathrm{Pt} / \mathrm{C}\left(0.8 \mathrm{mg} \mathrm{cm}^{-2}\right)$ catalyst, synthesized via the carbonyl method, in an $\mathrm{O}_{2}$-breathing LFFC. A commercial $30 \mathrm{wt} \% \mathrm{Pd} / \mathrm{C}\left(2 \mathrm{mg} \mathrm{cm} \mathrm{cm}^{-2}\right.$, E-TEK) catalyst was used as anode catalyst. (B) Polarization for 50 wt $\% \mathrm{Pt} / \mathrm{C}\left(5 \mathrm{mg} \mathrm{cm}^{-2}\right)$ catalyst, synthesized via the carbonyl method, in an $\mathrm{O}_{2}$-breathing LFFC. A non-polished Pd foil (Alfa Aesar) and a commercial $30 \mathrm{wt} \% \mathrm{Pd} / \mathrm{C}\left(2 \mathrm{mg} \mathrm{cm}{ }^{-2}\right.$, E-TEK) catalyst were used as anode catalysts. In both cases, $5 \mathrm{~m} \mathrm{HCOOH}$ was used as fuel and $0.5 \mathrm{M} \mathrm{H}_{2} \mathrm{SO}_{4}$ as electrolyte. The flow speed was $0.5 \mathrm{ml} \mathrm{min}^{-1}$. 
- Electrochemical evaluation of Pt/C catalyst for ORR [119, 120] and $\mathrm{HCOOH}$ (from fuel crossover) oxidation [131].

- Design and testing of an $\mathrm{O}_{2}$-breathing LFFC that has no polymer membrane [248, 265].

- Elaboration of fuel cell cathode: deposition of Pt/C catalyst on GDL (carbon paper) by the spraying technique [265].

- Fueling the LFFC with $\mathrm{HCOOH}$ and $\mathrm{O}_{2}$. The fuel cell generates enough energy to power a small electrical motor.

Thus, an example of nanoparticles for a low temperature electrochemical energy device is given. Finally, Figure 14B shows the current potential characteristics of a LFFC operating under similar conditions but with an anode made of a foil of Pd and the LFFC with a nanostructured anode of $30 \mathrm{wt} \%$ $\mathrm{Pd} / \mathrm{C}$. The differences between the characteristics are overwhelming. The generated electricity of the LFFC with the nanostructured anode is capable of powering a small electrical motor, whereas the LFFC with bulk Pd depolarizes very quickly. Figure 14B very clearly justifies the ultimate purpose of this review: how the performance of the electrochemical device can be increased by using less amounts of material, i.e., nanoparticles. The fact that a microfluidic electrochemical device is able to produce energy for portable applications is mainly due to progress in nanotechnology.

\subsection{Cathodes of Li-air batteries}

To conclude this review, one more example of electrochemical energy devices is illustrated: the Li-air battery. The maximum energy storage possible for a Li-ion battery rapidly reached its limits. Currently, Li-ion batteries are not sufficient for the needs of society, in particular, long-range electric vehicles. Li-air $\left(\mathrm{O}_{2}\right)$ and $\mathrm{Li}-\mathrm{S}$ batteries are two promising options [278]. The energy that can be stored in Li-air (based on aqueous or non-aqueous electrolytes) cells is noticeably quite superior to the Li-ion counterpart. Lithium can be used as an anode material for metal/air battery on the basis of an outstanding specific capacity (3842 $\mathrm{mAh} \mathrm{g}^{-1}$ for lithium vs. $815 \mathrm{mAh} \mathrm{g}^{-1}$ for zinc and $2965 \mathrm{mAh} \mathrm{g}^{-1}$ for aluminum) [279]. Li-air batteries are an alternative to classical Li-ion batteries because they have a very high specific energy density ranging from 5789 to $11248 \mathrm{Wh} \mathrm{kg}^{-1}$ [280]. These values are calculated according to the product formed on discharge and the electrolyte used. In Li-air batteries, whatever the electrolyte used, Li metal is oxidized into $\mathrm{Li}^{+}$(released into the electrolyte) on discharge and the reverse process occurs on charge. Limitations associated with this type of application are mainly due to electrochemical processes occurring at the cathode. At this electrode, $\mathrm{O}_{2}$ is reduced during discharge. The products formed during the reduction process depend on the type of electrolyte that is used. In an aprotic electrolyte $\mathrm{Li}_{2} \mathrm{O}_{2}$ [281] is formed although one can also observe the formation of $\mathrm{Li}_{2} \mathrm{O}$ [278]:

$$
\begin{array}{ll}
2 \mathrm{Li}^{+}+2 \mathrm{e}^{-}+\mathrm{O}_{2} \leftrightarrow \mathrm{Li}_{2} \mathrm{O}_{2} & E=2.96 \mathrm{~V} \text { vs. } \mathrm{Li}^{+} / \mathrm{Li} \\
4 \mathrm{Li}^{+}+4 \mathrm{e}^{-}+\mathrm{O}_{2} \leftrightarrow \mathrm{Li}_{2} \mathrm{O} & E=2.91 \mathrm{~V} \text { vs. } \mathrm{Li}^{+} / \mathrm{Li}
\end{array}
$$

The formation of $\mathrm{Li}_{2} \mathrm{O}$ allows increasing the stored energy but the oxide can be difficult to reverse on charging [282, 283].
In aqueous electrolyte, the product formed during discharge depends on the $\mathrm{pH}$ of the electrolyte. In alkaline medium, $\mathrm{LiOH}$ is formed and in an acidic one $\mathrm{H}_{2} \mathrm{O}$ is formed according to:

$$
\begin{aligned}
& 2 \mathrm{Li}^{+}+1 / 2 \mathrm{O}_{2}+\mathrm{H}_{2} \mathrm{O}+2 \mathrm{e}^{-} \leftrightarrow \mathrm{LiOH} \quad E=3.45 \mathrm{~V} \text { vs. } \mathrm{Li}^{+} / \mathrm{Li}(26) \\
& 1 / 2 \mathrm{O}_{2}+2 \mathrm{H}^{+}+2 \mathrm{e}^{-} \leftrightarrow \mathrm{H}_{2} \mathrm{O} \quad E=4.27 \mathrm{~V} \text { vs. } \mathrm{Li}^{+} / \mathrm{Li}
\end{aligned}
$$

The use of acidic electrolytes is of great interest because it could lead to the generation of higher voltages. Some challenges currently remain, blocking the large-scale production of Li-air batteries [284]. The first one consists of developing porous nanostructured cathodes capable of facilitating oxygen transport. Another problem associated with Li-air batteries in non-aqueous electrolytes is the deposition of insoluble and insulating products $\left(\mathrm{Li}_{2} \mathrm{O}_{2}\right.$ and $\left.\mathrm{Li}_{2} \mathrm{O}\right)$ in the cathode material. During the discharge process the deposition of these products is responsible for limitations of $\mathrm{Li}^{+}$ions, oxygen and electrons transport [285]. Additionally, the cathode catalyst has to be improved in order to enhance reaction kinetics and to reduce the energy loss associated with charge-discharge polarization. Two types of nanostructured catalysts are currently being developed: noble metal-based catalysts and oxide-based catalysts.

Among the oxide catalyst, $\alpha-\mathrm{MnO}_{2}[286]$ is the most promising one reaching a capacity of $3000 \mathrm{mAh} \mathrm{g}^{-1}$ in a non-aqueous electrolyte. For the same type of applications, other transition metal oxides such as $\mathrm{Fe}_{3} \mathrm{O}_{4}$ and $\mathrm{Co}_{3} \mathrm{O}_{4}$ have also been investigated [287]. Other efficient noble metal-based bifunctional catalysts have recently been developed for non-aqueous Li-air batteries. The Pt/C catalyst is very efficient for the OER and the $\mathrm{Au} / \mathrm{C}$ catalyst has a remarkable activity towards the ORR. Therefore, a nanostructured Pt-Au/C catalyst developed by $\mathrm{Lu}$ et al. [281] turned out to be a very efficient catalyst for the ORR in Li-air batteries. To reduce the cost of cathode materials, some non-precious catalysts containing $\mathrm{Mn}_{3} \mathrm{O}_{4}$ oxide were also developed [288]. Additionally, it is evident that due to their low cost and high electrochemical performances towards the ORR [93] in alkaline medium, Co-chalcogenides are good candidates as catalysts for the positive electrode of Li-air batteries. Moreover, it has been shown that $\mathrm{CoSe}_{2}$ modified by $\mathrm{Mn}_{3} \mathrm{O}_{4}$ nanoparticles, the resulting material, exhibits an unprecedented activity towards the OER in alkaline medium [289]. In fact, a current density of $10 \mathrm{~mA} \mathrm{~cm}^{-2}$ can be obtained at a very low overpotential $(0.45 \mathrm{~V})$. This is comparable to the performance of $\mathrm{Co}_{3} \mathrm{O}_{4}$ /graphene composite material which is one of the most performing, durable, low cost material for the ORR currently reported [290].

However, significant difficulties must be overcome and many issues have to be addressed to make Li-air batteries available for commercial applications. These problems include low electrolyte stability, poor round-trip efficiency, rate capability, life cycle and, of course, the ORR catalysts. Fundamental research in understanding the reactions occurring in Li-air $\left(\mathrm{O}_{2}\right)$ [291] as well as in new materials is urgently required [292].

\section{Outlook}

In this review, we have presented various chemical routes of synthesis of metal centered catalysts under mild conditions at 
the nanoscale domain and analyzed them as active centers for reactions carried out in low temperature fuel cells. The most important conclusion is that the synthesis method should be adapted to obtain monodispersed catalyst nanoparticles with well-defined sizes. Furthermore, a key statement to respect is the selectivity and tolerance of the anode and/or cathode catalytic center in order to avoid, as much as possible, the crossover effect. The property of some highly tolerant catalysts was put in evidence in laminar flow fuel cells, where the miniaturization is a highly demanding condition to manufacture microfluidic fuel system cells in the nanorange scale. We believe that the issues discussed in this review should be, as a central objective of contemporary catalysis research, to construct experimental models that can be directly compared with theory. One can name, e.g., interesting objectives to modify the nature of the substrate, a decrease of the loading of the catalyst based on one metal center, e.g., Pt, an alternative way to sustain molecular oxygen reduction yield to water, and chemical stability. Catalytic centers on appropriate substrates can positively influence ORR kinetics. Of course, there are some additional aspects such as the understanding of the electronic and geometric properties of the catalytic site. However, the ultimate goal is to decrease, as much as possible, the amount of amorphous carbon as a substrate concomitant to catalyst loading. Finally, knowledge of ORR catalysts can be translated to energy storage systems based on $\mathrm{Li}^{+}$-air. This domain is extremely important and interesting reports have started to emerge in the scientific literature.

\section{Acknowledgements}

The authors would like to thank all coworkers mentioned in the literature list. The work was partially supported by the University of Poitiers.

\section{References}

[1] Mond L, Langer C. A new form of gas battery. Proc. R. Soc. Lond. 1889, 46, 296-304.

[2] Turkevich J, Kim G. Palladium: preparation and catalytic properties of particles of uniform size. Science 1970, 169, 873-879.

[3] Bönnemann H, Brijoux W, Brinkmann R, Joußen T, Korall B, Dinjus E. Formation of colloidal transition metals in organic phases and their application in catalysis. Angew. Chem. Int. Ed. 1991, 30, 1312-1314.

[4] Boutonnet M, Kizling J, Stenius P, Maire G. The preparation of monodisperse colloidal metal particles from microemulsions. Colloid Surf. 1982, 5, 209-225.

[5] Iijima S. Helical microtubules of graphitic carbon. Nature 1991, $354,56-58$.

[6] Novoselov KS, Geim AK, Morozov SV, Jiang D, Zhang Y, Dubonos SV, Grigorieva IV, Firsov AA. Electric field effect in atomically thin carbon films. Science 2004, 306, 666-669.

[7] Prabhuram J, Wang X, Hui CL, Hsing IM. Synthesis and characterization of surfactant-stabilized $\mathrm{Pt} / \mathrm{C}$ nanocatalysts for fuel cell applications. J. Phys. Chem. B 2003, 107, 11057-11064.

[8] Gilliam R, Kirk D, Thorpe S. Part 1 - Structure-sensitivity of nanoparticle catalysts: relating current theories to experimental data. Electrocatalysis 2012, 3, 68-74.
[9] Miller JT, Kropf AJ, Zha Y, Regalbuto JR, Delannoy L, Louis C, Bus E, van Bokhoven JA. The effect of gold particle size on $\mathrm{AuAu}$ bond length and reactivity toward oxygen in supported catalysts. J. Catal. 2006, 240, 222-234.

[10] Visikovskiy A, Matsumoto H, Mitsuhara K, Nakada T, Akita T, Kido Y. Electronic d-band properties of gold nanoclusters grown on amorphous carbon. Phys. Rev. B 2011, 83, 165428.

[11] Hammer B, Norskov JK. Why gold is the noblest of all the metals. Nature 1995, 376, 238-240.

[12] Hammer B, Nørskov JK. Electronic factors determining the reactivity of metal surfaces. Surf. Sci. 1995, 343, 211-220.

[13] Ruban A, Hammer B, Stoltze P, Skriver HL, Nørskov JK. Surface electronic structure and reactivity of transition and noble metals. J. Mol. Catal. A Chem. 1997, 115, 421-429.

[14] Christoffersen E, Liu P, Ruban A, Skriver HL, Nørskov JK. Anode materials for low-temperature fuel cells: a density functional theory study. J. Catal. 2001, 199, 123-131.

[15] Greeley J, Nørskov JK, Mavrikakis M. Electronic structure and catalysis on metal surfaces. Annu. Rev. Phys. Chem. 2002, 53, 319-348.

[16] Casillas G, Velázquez-Salazar JJ, Jose-Yacaman M. A new mechanism of stabilization of large decahedral nanoparticles. J. Phys. Chem. C 2012, 116, 8844-8848.

[17] Barnard AS. A thermodynamic model for the shape and stability of twinned nanostructures. J. Phys. Chem. B 2006, 110, 24498-24504.

[18] Burda C, Chen X, Narayanan R, El-Sayed MA. Chemistry and properties of nanocrystals of different shapes. Chem. Rev. 2005, $105,1025-1102$.

[19] Park J, Joo J, Kwon SG, Jang Y, Hyeon T. Synthesis of monodisperse spherical nanocrystals. Angew. Chem. Int. Ed. 2007, 46, 4630-4660.

[20] Tang S, Chen L, Vongehr S, Meng X. Heterogeneous nucleation and growth of silver nanoparticles on unmodified polystyrene spheres by in situ reduction. Appl. Surf. Sci. 2010, 256, 2654-2660.

[21] Peng Z, Yang H. Designer platinum nanoparticles: control of shape, composition in alloy, nanostructure and electrocatalytic property. Nano Today 2009, 4, 143-164.

[22] Tai CY, Wu J-F, Rousseau RW. Interfacial supersaturation, secondary nucleation, and crystal growth. J. Crystal Growth 1992, 116, 294-306.

[23] LaMer VK, Dinegar RH. Theory, production and mechanism of formation of monodispersed hydrosols. J. Am. Chem. Soc. 1950, 72, 4847-4854.

[24] Tartaj P, del Puerto Morales M, Ventemillas-Verdaguer S, Gonzales-Carreno T, Serna CJ. The preparation of magnetic nanoparticles for applications in biomedicine. J. Phys. D Appl. Phys. 2003, 36, R182-R197.

[25] Kabalnov AS, Shchukin ED. Ostwald ripening theory: applications to fluorocarbon emulsion stability. Adv. Colloid Interf. Sci. 1992, 38, 69-97.

[26] Peng X, Wickham J, Alivisatos AP. Kinetics of II-VI and III-V colloidal semiconductor nanocrystal growth: "focusing" of size distributions. J. Am. Chem. Soc. 1998, 120, 5343-5344.

[27] Yu H, Gibbons PC, Kelton KF, Buhro WE. Heterogeneous seeded growth: a potentially general synthesis of monodisperse metallic nanoparticles. J. Am. Chem. Soc. 2001, 123, 9198-9199.

[28] Hambrock J, Becker R, Birkner A, Weiss J, Fischer RA. A non-aqueous organometallic route to highly monodispersed copper nanoparticles using $\left[\mathrm{Cu}\left(\mathrm{OCH}(\mathrm{Me}) \mathrm{CH}_{2} \mathrm{NMe}_{2}\right)_{2}\right]$. Chem. Commun. 2002, 38, 68-69. 
[29] Yu WW, Falkner JC, Yavuz CT, Colvin VL. Synthesis of monodisperse iron oxide nanocrystals by thermal decomposition of iron carboxylate salts. Chem. Commun. 2004, 40, 2306-2307.

[30] Wulff G. Zur Frage der Geschwindigkeit des Wachsthums und der Aufloesung der Krystallflachen. Z. Kristallogr. Mineral. 1901, 34, 449-530.

[31] Tao AR, Habas S, Yang P. Shape control of colloidal metal nanocrystals. Small 2008, 4, 310-325.

[32] Elechiguerra JL, Reyes-Gasga J, Yacaman MJ. The role of twinning in shape evolution of anisotropic noble metal nanostructures. J. Mater. Chem. 2006, 16, 3906-3919.

[33] Hofmeister H. Fivefold twinned nanoparticles. In Encyclopedia of Nanoscience and Nanotechnology, Nalwa HS, Ed., American Scientific Publisher: Stevenson Ranch, CA, 2004, pp. 431-452.

[34] Dahmen U, Hetherington CJD, Radmilovic V, Johnson E, Xiao $\mathrm{SQ}$, Luo CP. Electron microscopy observations on the role of twinning in the evolution of microstructures. Microscop. Microanal. 2002, 8, 247-256.

[35] Esparza R, Rosas G, Valenzuela E, Gamboa SA, Pal U, Pérez R. Structural analysis and shape-dependent catalytic activity of $\mathrm{Au}, \mathrm{Pt}$ and Au/Pt nanoparticles. Rev. Mat. 2008, 13, 579-586.

[36] Hofmeister H. Forty years study of fivefold twinned structures in small particles and thin films. Cryst. Res. Technol. 1998, 33, 3-25.

[37] Capek I. Preparation of metal nanoparticles in water-in-oil (w/o) microemulsions. Adv. Colloid Interf. Sci. 2004, 110, 49-74.

[38] Solla-Gullón J, Vidal-Iglesias FJ, Montiel V, Aldaz A. Electrochemical characterization of platinum-ruthenium nanoparticles prepared by water-in-oil microemulsion. Electrochim. Acta 2004, 49, 5079-5088.

[39] Solla-Gullón J, Rodes A, Montiel V, Aldaz A, Clavilier J. Electrochemical characterisation of platinum-palladium nanoparticles prepared in a water-in-oil microemulsion. J. Electroanal. Chem. 2003, 554-555, 273-284.

[40] Njoki PN, Luo J, Wang L, Maye MM, Quaizar H, Zhong C-J. Platinum-catalyzed synthesis of water-soluble gold-platinum nanoparticles. Langmuir 2005, 21, 1623-1628.

[41] Destrée C, Nagy JB. Mechanism of formation of inorganic and organic nanoparticles from microemulsions. Adv. Colloid Interf. Sci. 2006, 123-126, 353-367.

[42] Tojo C, Blanco MC, Rivadulla F, López-Quintela MA. Kinetics of the formation of particles in microemulsions. Langmuir 1997, 13, 1970-1977.

[43] Eriksson S, Nylén U, Rojas S, Boutonnet M. Preparation of catalysts from microemulsions and their applications in heterogeneous catalysis. Appl. Catal. A Gen. 2004, 265, 207-219.

[44] Paul BK, Mitra RK. Water solubilization capacity of mixed reverse micelles: effect of surfactant component, the nature of the oil, and electrolyte concentration. J. Colloid Interf. Sci. 2005, 288, 261-279.

[45] Bönnemann H, Braun G, Brijoux W, Brinkmann R, Tilling AS, Seevogel K, Siepen K. Nanoscale colloidal metals and alloys stabilized by solvents and surfactants. Preparation and use as catalyst precursors. J. Organomet. Chem. 1996, 520, 143-162.

[46] FievetF, Lagier JP, Blin B, Beaudoin B, Figlarz M. Homogeneous and heterogeneous nucleations in the polyol process for the preparation of micron and submicron size metal particles. Solid State Ionics 1989, 32-33, 198-205.

[47] Grolleau C, Coutanceau C, Pierre F, Leger JM. Optimization of a surfactant free polyol method for the synthesis of platinum-cobalt electrocatalysts using Taguchi design of experiments. J. Power Sources 2010, 195, 1569-1576.
[48] Yang H, Alonso-Vante N, Léger J-M, Lamy C. Tailoring, structure, and activity of carbon-supported nanosized $\mathrm{Pt}-\mathrm{Cr}$ alloy electrocatalysts for oxygen reduction in pure and methanol-containing electrolytes. J. Phys. Chem. B 2004, 108, 1938-1947.

[49] Alonso-Vante N. Carbonyl tailored electrocatalysts. Fuel Cells 2006, 6, 182-189.

[50] Le Rhun V, Garnier E, Pronier S, Alonso-Vante N. Electrocatalysis on nanoscale ruthenium-based material manufactured by carbonyl decomposition. Electrochem. Commun. 2000, 2, 475-479.

[51] Fujiwara N, Yamazaki S-i, Siroma Z, Ioroi T, Senoh H, Yasuda K. Nonenzymatic glucose fuel cells with an anion exchange membrane as an electrolyte. Electrochem. Commun. 2009, 11, 390-392.

[52] Demirci UB. Direct liquid-feed fuel cells: thermodynamic and environmental concerns. J. Power Sources 2007, 169, 239-246.

[53] Kerzenmacher S, Ducrée J, Zengerle R, von Stetten F. Energy harvesting by implantable abiotically catalyzed glucose fuel cells. J. Power Sources 2008, 182, 1-17.

[54] Breiter MW. Comparative voltammetric study of methanol oxidation and adsorption on noble metal electrodes in perchloric acid solutions. Electrochim. Acta 1962, 8, 973-983.

[55] Greeley J, Mavrikakis M. A first-principles study of methanol decomposition on $\mathrm{Pt}(111)$. J. Am. Chem. Soc. 2002, 124, 7193-7201.

[56] Cao D, Lu GQ, Wieckowski A, Wasileski SA, Neurock M. Mechanisms of methanol decomposition on platinum: a combined experimental and ab initio approach. J. Phys. Chem. B 2005, 109, 11622-11633.

[57] Korzeniewski C, Childers CL. Formaldehyde yields from methanol electrochemical oxidation on platinum. J. Phys. Chem. B 1998, 102, 489-492.

[58] Iwasita T, Vielstich W. On-line mass spectroscopy of volatile products during methanol oxidation at platinum in acid solutions. J. Electroanal. Chem. Interfac. Electrochem. 1986, 201, 403-408.

[59] Wasmus S, Küver A. Methanol oxidation and direct methanol fuel cells: a selective review. J. Electroanal. Chem. 1999, 461, 14-31.

[60] Paulus UA, Endruschat U, Feldmeyer GJ, Schmidt TJ, Bönnemann H, Behm RJ. New PtRu alloy colloids as precursors for fuel cell catalysts. J. Catal. 2000, 195, 383-393.

[61] Antolini E. Formation of carbon-supported PtM alloys for low temperature fuel cells: a review. Mater. Chem. Phys. 2003, 78, 563-573.

[62] Lu G-Q, Wieckowski A. Heterogeneous electrocatalysis: a core field of interfacial science. Curr. Opin. Colloid Interf. Sci. 2000, 5, 95-100.

[63] ReddingtonE, SapienzaA, Gurau B, Viswanathan R, Sarangapani S, Smotkin ES, Mallouk TE. Combinatorial electrochemistry: a highly parallel, optical screening method for discovery of better electrocatalysts. Science 1998, 280, 1735-1737.

[64] de la Fuente JLG, Martínez-Huerta MV, Rojas S, Terreros P, Fierro JLG, Peña MA. Methanol electrooxidation on PtRu nanoparticles supported on functionalised carbon black. Catal. Today 2006, 116, 422-432.

[65] Watanabe M, Uchida M, Motoo S. Preparation of highly dispersed $\mathrm{Pt}+\mathrm{Ru}$ alloy clusters and the activity for the electrooxidation of methanol. J. Electroanal. Chem. Interfac. Electrochem. 1987, 229, 395-406.

[66] Liang Y, Zhang H, Zhong H, Zhu X, Tian Z, Xu D, Yi B. Preparation and characterization of carbon-supported PtRuIr 
catalyst with excellent CO-tolerant performance for proton-exchange membrane fuel cells. J. Catal. 2006, 238, 468-476.

[67] Shao Z-G, Zhu F, Lin W-F, Christensen PA, Zhang H. PtRu/Ti anodes with varying $\mathrm{Pt}$ ratio: Ru ratio prepared by electrodeposition for the direct methanol fuel cell. Phys. Chem. Chem. Phys. 2006, 8, 2720-2726.

[68] Liu Z, Lee JY, Han M, Chen W, Gan LM. Synthesis and characterization of $\mathrm{PtRu} / \mathrm{C}$ catalysts from microemulsions and emulsions. J. Mater. Chem. 2002, 12, 2453-2458.

[69] Mott D, Luo J, Njoki PN, Lin Y, Wang L, Zhong C-J. Synergistic activity of gold-platinum alloy nanoparticle catalysts. Catal. Today 2007, 122, 378-385.

[70] Habrioux A, Sibert E, Servat K, Vogel W, Kokoh KB, AlonsoVante N. Activity of platinum-gold alloys for glucose electrooxidation in biofuel cells. J. Phys. Chem. B 2007, 111, 10329-10333.

[71] Luo J, Maye MM, Kariuki NN, Wang L, Njoki P, Lin Y, Schadt M, Naslund HR, Zhong C-J. Electrocatalytic oxidation of methanol: carbon-supported gold-platinum nanoparticle catalysts prepared by two-phase protocol. Catal. Today 2005, 99, 291-297.

[72] Rice C, Ha S, Masel RI, Waszczuk P, Wieckowski A, Barnard T. Direct formic acid fuel cells. J. Power Sources 2002, 111, 83-89.

[73] Capon A, Parsons R. The oxidation of formic acid at noble metal electrodes. Part III. Intermediates and mechanism on platinum electrodes. J. Electroanal. Chem. Interfac. Electrochem. 1973, 45, 205-231.

[74] Lu G-Q, Crown A, Wieckowski A. Formic acid decomposition on polycrystalline platinum and palladized platinum electrodes. J. Phys. Chem. B 1999, 103, 9700-9711.

[75] Largeaud F, Kokoh KB, Beden B, Lamy C. On the electrochemical reactivity of anomers: electrocatalytic oxidation of $\alpha$ - and $\beta$-D-glucose on platinum electrodes in acid and basic media. J. Electroanal. Chem. 1995, 397, 261-269.

[76] Sun Y, Buck H, Mallouk TE. Combinatorial discovery of alloy electrocatalysts for amperometric glucose sensors. Anal. Chem. 2001, 73, 1599-1604.

[77] Kokoh KB, Léger JM, Beden B, Huser H, Lamy C. "On line" chromatographic analysis of the products resulting from the electrocatalytic oxidation of D-glucose on pure and adatoms modified Pt and Au electrodes - Part II. Alkaline medium. Electrochim. Acta 1992, 37, 1909-1918.

[78] Rao MLB, Drake RF. Studies of electrooxidation of dextrose in neutral media. J. Electrochem. Soc. 1969, 116, 334-337.

[79] Ernst S, Heitbaum J, Hamann CH. The electrooxidation of glucose in phosphate buffer solutions: Part I. Reactivity and kinetics below $350 \mathrm{mV} / \mathrm{RHE}$. J. Electroanal. Chem. Interfac. Electrochem. 1979, 100, 173-183.

[80] Bae IT, Yeager E, Xing X, Liu CC. In situ infrared studies of glucose oxidation on platinum in an alkaline medium. J. Electroanal. Chem. Interf. Electrochem. 1991, 309, 131-145.

[81] Bae IT, Xing X, Liu CC, Yeager E. In situ Fourier transform infrared reflection absorption spectroscopic studies of glucose oxidation on platinum in acid. J. Electroanal. Chem. Interf. Electrochem. 1990, 284, 335-349.

[82] Park S, Boo H, Chung TD. Electrochemical non-enzymatic glucose sensors. Anal. Chim. Acta 2006, 556, 46-57.

[83] Becerik I, Kadirgan F. Glucose sensitivity of platinum-based alloys incorporated in polypyrrole films at neutral media. Synthet. Metals 2001, 124, 379-384.
[84] Habrioux A, Servat K, Tingry S, Kokoh KB. Enhancement of the performances of a single concentric glucose $/ \mathrm{O}_{2}$ biofuel cell by combination of bilirubin oxidase/Nafion cathode and $\mathrm{Au}-\mathrm{Pt}$ anode. Electrochem. Commun. 2009, 11, 111-113.

[85] Möller H, Pistorius PC. The electrochemistry of gold-platinum alloys. J. Electroanal. Chem. 2004, 570, 243-255.

[86] Jin C, Chen Z. Electrocatalytic oxidation of glucose on gold-platinum nanocomposite electrodes and platinummodified gold electrodes. Synthet. Metals 2007, 157, 592-596.

[87] Basu D, Basu S. Synthesis and characterization of Pt-Au/C catalyst for glucose electro-oxidation for the application in direct glucose fuel cell. Int. J. Hydrog. Energy 2011, 36, 14923-14929.

[88] Damjanovic A, Genshaw MA, Bockris JOM. Distinction between intermediates produced in main and side electrodic reactions. J. Chem. Phys. 1966, 45, 4057-4059.

[89] Damjanovic A, Genshaw MA, Bockris JOM. The mechanism of oxygen reduction at platinum in alkaline solutions with special reference to $\mathrm{H}_{2} \mathrm{O}_{2}$. J. Electrochem. Soc. 1967, 114, 1107-1112.

[90] Nørskov JK, Rossmeisl J, Logadottir A, Lindqvist L, Kitchin JR, Bligaard T, Jonsson H. Origin of the overpotential for oxygen reduction at a fuel-cell cathode. J. Phys. Chem. B 2004, 108, 17886-17892.

[91] Alonso-Vante N. Platinum and non-platinum nanomaterials for the molecular oxygen reduction reaction. Chemphyschem 2010, 11, 2732-2744.

[92] Lefèvre M, Dodelet J-P. Fe-based electrocatalysts made with microporous pristine carbon black supports for the reduction of oxygen in PEM fuel cells. Electrochim. Acta 2008, 53, 8269-8276.

[93] Feng Y, Alonso-Vante N. Carbon-supported cubic $\mathrm{CoSe}_{2}$ catalysts for oxygen reduction reaction in alkaline medium. Electrochim. Acta 2012, 72, 129-133.

[94] González Huerta RG, Valenzuela MA, Vargas García R, Alonso-Vante N, Tufiño Velázquez M, Ruiz-Camacho B. Oxygen reduction performance of $\mathrm{Pt} / \mathrm{TiO}_{2}-\mathrm{C}$ electrocatalyst prepared by two-step chemical vapor deposition. J. New Mater. Electrochem. Syst. 2012, 15, 123-128.

[95] Favry E, Wang D, Fantauzzi D, Anton J, Su DS, Jacob T, Alonso-Vante N. Synthesis, electrochemical characterization and molecular dynamics studies of surface segregation of platinum nano-alloy electrocatalysts. Phys. Chem. Chem. Phys. 2011, 13, 9201-9208.

[96] Minhua S. Palladium-based electrocatalysts for hydrogen oxidation and oxygen reduction reactions. J. Power Sources 2011, 196, 2433-2444.

[97] Zhang J, Vukmirovic MB, Sasaki K, Nilekar AU, Mavrikakis M, Adzic RR. Mixed-metal Pt monolayer electrocatalysts for enhanced oxygen reduction kinetics. J. Am. Chem. Soc. 2005, $127,12480-12481$.

[98] Othman R, Dicks AL, Zhu Z. Non precious metal catalysts for the PEM fuel cell cathode. Int. J. Hydrog. Energy 2012, 37, 357-372.

[99] Jaouen F, Proietti E, Lefevre M, Chenitz R, Dodelet J-P, Wu G, Chung HT, Johnston CM, Zelenay P. Recent advances in nonprecious metal catalysis for oxygen-reduction reaction in polymer electrolyte fuel cells. Energy Environ. Sci. 2011, 4, 114-130.

[100] Matter PH, Zhang L, Ozkan US. The role of nanostructure in nitrogen-containing carbon catalysts for the oxygen reduction reaction. J. Catal. 2006, 239, 83-96.

[101] Calvillo L, Lázaro MJ, García-Bordejé E, Moliner R, Cabot PL, Esparbé I, Pastor E, Quintana JJ. Platinum supported on 
functionalized ordered mesoporous carbon as electrocatalyst for direct methanol fuel cells. J. Power Sources 2007, 169, 59-64.

[102] Guilminot E, Fischer F, Chatenet M, Rigacci A, BerthonFabry S, Achard P, Chainet E. Use of cellulose-based carbon aerogels as catalyst support for PEM fuel cell electrodes: electrochemical characterization. J. Power Sources 2007, 166, 104-111.

[103] Matter PH, Wang E, Arias M, Biddinger EJ, Ozkan US. Oxygen reduction reaction activity and surface properties of nanostructured nitrogen-containing carbon. J. Mol. Catal. A Chem. 2007, 264, 73-81.

[104] Ambrosio EP, Francia C, Manzoli M, Penazzi N, Spinelli P. Platinum catalyst supported on mesoporous carbon for PEMFC. Int. J. Hydrog. Energy 2008, 33, 3142-3145.

[105] Chen XL, Li WS, Tan CL, Li W, Wu YZ. Improvement in electrochemical capacitance of carbon materials by nitric acid treatment. J. Power Sources 2008, 184, 668-674.

[106] Guilminot E, Gavillon R, Chatenet M, Berthon-Fabry S, Rigacci A, Budtova T. New nanostructured carbons based on porous cellulose: elaboration, pyrolysis and use as platinum nanoparticles substrate for oxygen reduction electrocatalysis. J. Power Sources 2008, 185, 717-726.

[107] Fang B, Kim JH, Kim M, Yu J-S. Ordered hierarchical nanostructured carbon as a highly efficient cathode catalyst support in proton exchange membrane fuel cell. Chem. Mater. 2009, 21, 789-796.

[108] Kongkanand A, Kuwabata S, Girishkumar G, Kamat P. Singlewall carbon nanotubes supported platinum nanoparticles with improved electrocatalytic activity for oxygen reduction reaction. Langmuir 2006, 22, 2392-2396.

[109] Vijayaraghavan G, Stevenson KJ. Synergistic assembly of dendrimer-templated platinum catalysts on nitrogen-doped carbon nanotube electrodes for oxygen reduction. Langmuir 2007, 23, 5279-5282.

[110] Maldonado S, Stevenson KJ. Influence of nitrogen doping on oxygen reduction electrocatalysis at carbon nanofiber electrodes. J. Phys. Chem. B 2005, 109, 4707-4716.

[111] Hasché F, Oezaslan M, Strasser P. Activity, stability and degradation of multi walled carbon nanotube (MWCNT) supported Pt fuel cell electrocatalysts. Phys. Chem. Chem. Phys. 2010, 12, 15251-15258.

[112] Kinoshita K. Carbon: Electrochemical and Physicochemical Properties, Wiley: New York, 1988.

[113] Borup R, Meyers J, Pivovar B, Kim YS, Mukundan R, Garland N, Myers D, Wilson M, Garzon F, Wood D, Zelenay P, More K, Stroh K, Zawodzinski T, Boncella J, McGrath JE, Inaba M, Miyatake K, Hori M, Ota K, Ogumi Z, Miyata S, Nishikata A, Siroma Z, Uchimoto Y, Yasuda K, Kimijima K-i, Iwashita N. Scientific aspects of polymer electrolyte fuel cell durability and degradation. Chem. Rev. 2007, 107, 3904-3951.

[114] Manzo-Robledo A, Boucher AC, Pastor E, Alonso-Vante N. Electro-oxidation of carbon monoxide and methanol on carbon-supported Pt-Sn nanoparticles: a DEMS study. Fuel Cells 2002, 2, 109-116.

[115] Wang Z, Zuo P, Chu Y, Shao Y, Yin G. Durability studies on performance degradation of $\mathrm{Pt} / \mathrm{C}$ catalysts of proton exchange membrane fuel cell. Int. J. Hydrog. Energy 2009, 34, 4387-4394.

[116] Chaparro A, Mueller N, Atienza C, Daza L. Study of electrochemical instabilities of PEMFC electrodes in aqueous solution by means of membrane inlet mass spectrometry. J. Electroanal. Chem. 2006, 591, 69-73.
[117] Sharma S, Pollet BG. Support materials for PEMFC and DMFC electrocatalysts - a review. J. Power Sources 2012, 208, 96-119.

[118] Tauster S, Fung S, Garten R. Strong metal-support interactions. Group 8 noble metals supported on titanium dioxide. J. Am. Chem. Soc. 1978, 100, 170-175.

[119] Vogel W, Timperman L, Alonso-Vante N. Probing metal substrate interaction of Pt nanoparticles: structural XRD analysis and oxygen reduction reaction. Appl. Catal. A Gen. 2010, 377, $167-173$

[120] Timperman L, Feng YJ, Vogel W, Alonso-Vante N. Substrate effect on oxygen reduction electrocatalysis. Electrochim. Acta 2010, 55, 7558-7563.

[121] Yu Y, Li H, Wang H, Yuan X-Z, Wang G, Pan M. A review on performance degradation of proton exchange membrane fuel cells during startup and shutdown processes: causes, consequences, and mitigation strategies. J. Power Sources 2012, 205, 10-23.

[122] Subban C, Zhou Q, Hu A, Moylan TE, Wagner FT, DiSalvo FJ. Sol-gel synthesis, electrochemical characterization, and stability testing of $\mathrm{Ti}_{0.7} \mathrm{~W}_{0.3} \mathrm{O}_{2}$ nanoparticles for catalyst support applications in proton-exchange membrane fuel cells. J. Am. Chem. Soc. 2010, 132, 17531-17536.

[123] Wang D, Subban C, Wang H, Rus E, DiSalvo F, Abruña H. Highly stable and CO-tolerant $\mathrm{Pt} / \mathrm{Ti}_{0.7} \mathrm{~W}_{0.3} \mathrm{O}_{2}$ electrocatalyst for proton-exchange membrane fuel cells. J. Am. Chem. Soc. 2010, 132, 10218-10220.

[124] Aryanpour M, Hoffmann R, Disalvo FJ. Tungsten-doped titanium dioxide in the rutile structure: theoretical considerations. Chem. Mater. 2009, 21, 1627-1635.

[125] Abadias G, Gago A, Alonso-Vante N. Structural and photoelectrochemical properties of Ti1-xWxO2 thin films deposited by magnetron sputtering. Surf. Coat. Technol. 2011, 205, S265-S270.

[126] Lee S, Kim H, Jung K, Kim H, Shul Y. Photocatalytic activity of metal ion (Fe or W) doped titania. Korean J. Chem. Eng. 2001, 18, 914-918.

[127] Michalow KA, Vital A, Heel A, Graule T, Reifler FA, Ritter A, Zakrzewska K, Rekas M. Photocatalytic activity of W-doped $\mathrm{TiO}_{2}$ nanopowders. J. Adv. Oxidat. Technol. 2008, 11, 56-64.

[128] Couselo N, Garciaeinschlag FS, Candal RJ, Jobbagy M. Tungsten-doped $\mathrm{TiO}_{2}$ vs pure $\mathrm{TiO}_{2}$ photocatalysts: effects on photobleaching kinetics and mechanism. J. Phys. Chem. C 2008, 112, 1094-1100.

[129] Huang J, Li Y, Zhao G, Cai X. Photocatalytic degradation characteristic of amorphous $\mathrm{TiO}_{2}-\mathrm{W}$ thin films deposited by magnetron sputtering. Trans. Nonferrous Metals Soc. China 2006, 16, 280-284.

[130] Chen D-M, Xu G, Miao L, Chen L-H, Nakao S, Jin P. W-doped anatase $\mathrm{TiO}_{2}$ transparent conductive oxide films: theory and experiment. J. Appl. Phys. 2010, 107, 063707.

[131] Timperman L, Gago AS, Alonso-Vante N. Oxygen reduction reaction increased tolerance and fuel cell performance of $\mathrm{Pt}$ and $\mathrm{Ru}_{\mathrm{x}} \mathrm{Se}_{\mathrm{y}}$ onto oxide-carbon composites. J. Power Sources 2011, 196, 4290-4297.

[132] Xiong L, Manthiram A. Synthesis and characterization of methanol tolerant $\mathrm{Pt} / \mathrm{TiO}_{\mathrm{x}} / \mathrm{C}$ nanocomposites for oxygen reduction in direct methanol fuel cells. Electrochim. Acta 2004, 49, 4163-4170.

[133] Chen C, Pan F. Electrocatalytic activity of Pt nanoparticles deposited on porous $\mathrm{TiO}_{2}$ supports toward methanol oxidation. Appl. Catal. B: Environ. 2009, 91, 663-669. 
[134] Selvarani G, Maheswari S, Sridhar P, Pitchumani S, Shukla AK. Carbon-supported $\mathrm{Pt}-\mathrm{TiO}_{2}$ as a methanol-tolerant oxygenreduction catalyst for DMFCs. J. Electrochem. Soc. 2009, 156, B1354-B1360.

[135] Hepel M, Dela I, Hepel T, Luo J, Zhong C. Novel dynamic effects in electrocatalysis of methanol oxidation on supported nanoporous $\mathrm{TiO}_{2}$ bimetallic nanocatalysts. Electrochim. Acta 2007, 52, 5529-5547.

[136] Seger B, Kongkanand A, Vinodgopal K, Kamat PV. Platinum dispersed on silica nanoparticle as electrocatalyst for PEM fuel cell. J. Electroanal. Chem. 2008, 621, 198-204.

[137] Sasaki K, Zhang L, Adzic RR. Niobium oxide-supported platinum ultra-low amount electrocatalysts for oxygen reduction. Phys. Chem. Chem. Phys. 2008, 10, 159-167.

[138] Elezovic NR, Babic BM, Radmilovic VR, Vracar LM, Krstajic NV. Synthesis and characterization of $\mathrm{MoO}_{\mathrm{x}}-\mathrm{Pt} / \mathrm{C}$ and $\mathrm{TiO}_{\mathrm{x}}-$ $\mathrm{Pt} / \mathrm{C}$ nano-catalysts for oxygen reduction. Electrochim. Acta 2009, 54, 2404-2409.

[139] Saha MS, Banis MN, Zhang Y, Li R, Sun X, Cai M, Wagner FT. Tungsten oxide nanowires grown on carbon paper as $\mathrm{Pt}$ electrocatalyst support for high performance proton exchange membrane fuel cells. J. Power Sources 2009, 192, 330-335.

[140] Kulesza P, Miecznikowski K, Baranowska B, Skunik M, Kolary-Zurowska A, Lewera A, Karnicka K, Chojak M, Rutkowska I, Fiechter S, Bogdanoff P, Dorbandt I, Zehl G, Hiesgen R, Dirk E, Nagabhushana K, Boennemann H. Electroreduction of oxygen at tungsten oxide modified carbon-

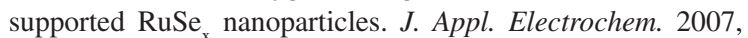
37, 1439-1446.

[141] Matsui T, Fujiwara K, Okanishi T, Kikuchi R, Takeguchi T, Eguchi K. Electrochemical oxidation of $\mathrm{CO}$ over tin oxide supported platinum catalysts. J. Power Sources 2006, 155, 152-156.

[142] Shim J, Lee C-R, Lee H-K, Lee J-S, Cairns EJ. Electrochemical characteristics of $\mathrm{Pt}-\mathrm{WO}_{3} / \mathrm{C}$ and $\mathrm{Pt}-\mathrm{TiO}_{2} / \mathrm{C}$ electrocatalysts in a polymer electrolyte fuel cell. J. Power Sources 2001, 102, 172-177.

[143] Gustavsson M, Ekström H, Hanarp P, Eurenius L, Lindbergh G, Olsson E, Kasemo B. Thin film Pt/TiO, catalysts for the polymer electrolyte fuel cell. J. Power Sources 2007, 163, 671-678.

[144] von Kraemer S, Wikander K, Lindbergh G, Lundblad A, Palmqvist AEC. Evaluation of $\mathrm{TiO}_{2}$ as catalyst support in $\mathrm{Pt}-\mathrm{TiO}_{2} / \mathrm{C}$ composite cathodes for the proton exchange membrane fuel cell. J. Power Sources 2008, 180, 185-190.

[145] de Tacconi NR, Chenthamarakshan CR, Rajeshwar K, Lin W-Y, Carlson TF, Nikiel L, Wampler WA, Sambandam S, Ramani V. Photocatalytically generated $\mathrm{Pt} / \mathrm{C}-\mathrm{TiO}_{2}$ electrocatalysts with enhanced catalyst dispersion for improved membrane durability in polymer electrolyte fuel cells. J. Electrochem. Soc. 2008, 155, B1102-B1109.

[146] Zhang H, Zhou W, Du Y, Yang P, Wang C, Xu J. Enhanced electrocatalytic performance for methanol oxidation on Pt$\mathrm{TiO}_{2} / \mathrm{ITO}$ electrode under UV illumination. Int. J. Hydrog. Energy 2010, 35, 13290-13297.

[147] Xie X-Y, Ma Z-F, Wu X, Ren Q-Z, Yuan X, Jiang Q-Z, Hu L. Preparation and electrochemical characteristics of CoTMPP$\mathrm{TiO}_{2}$ NT/BP composite electrocatalyst for oxygen reduction reaction. Electrochim. Acta 2007, 52, 2091-2096.

[148] Saha M, Banis M, Zhang Y, Li R, Sun X, Cai M, Wagner F. Tungsten oxide nanowires grown on carbon paper as Pt electrocatalyst support for high performance proton exchange membrane fuel cells. J. Power Sources 2009, 192, 330-335.
[149] Antolini E, Gonzalez ER. Tungsten-based materials for fuel cell applications. Appl. Catal. B Environ. 2010, 96, 245-266.

[150] Saha MS, Zhang Y, Cai M, Sun X. Carbon-coated tungsten oxide nanowires supported Pt nanoparticles for oxygen reduction. Int. J. Hydrog. Energy 2011, 37, 4633-4638.

[151] Sugimura H, Uchida T, Kitamura N, Masuhara H. Photocatalytic micropatterning of titanium oxide surface with platinum. Chem. Lett. 1993, 2, 379-382.

[152] Wang X, Wang J, Zou Q, Xia Y. Pd nanoparticles supported on carbon-modified rutile $\mathrm{TiO}_{2}$ as a highly efficient catalyst for formic acid electrooxidation. Electrochim. Acta 2010, 56, 1646-1651.

[153] Yoo S, Jeon T, Lee K, Park K, Sung Y. Effects of particle size on surface electronic and electrocatalytic properties of $\mathrm{Pt} / \mathrm{TiO}_{2}$ nanocatalysts. Chem. Commun. 2010, 46, 794-796.

[154] Formo E, Peng Z, Lee E, Lu X, Yang H, Xia Y. Direct oxidation of methanol on Pt nanostructures supported on electrospun nanofibers of anatase. J. Phys. Chem. C 2008, 112, 9970-9975.

[155] Croy J, Mostafa S, Liu J, Sohn Y, Heinrich H, Cuenya B. Support dependence of $\mathrm{MeOH}$ decomposition over size-selected Pt nanoparticles. Catal. Lett. 2007, 119, 209-216.

[156] Morales-Acosta D, Ledesma-Garcia J, Godinez L, Rodríguez H, Álvarez-Contreras L, Arriaga L. Development of Pd and Pd-Co catalysts supported on multi-walled carbon nanotubes for formic acid oxidation. J. Power Sources 2010, 195, 461-465.

[157] Shao Y, Yin G, Wang J, Gao Y, Shi P. Multi-walled carbon nanotubes based Pt electrodes prepared with in situ ion exchange method for oxygen reduction. J. Power Sources 2006, 161, $47-53$.

[158] Selvaraj V, Alagar M. Pt and Pt-Ru nanoparticles decorated polypyrrole/multiwalled carbon nanotubes and their catalytic activity towards methanol oxidation. Electrochem. Commun. 2007, 9, 1145-1153.

[159] Xu J, Hua K, Sun G, Wang C, Lv X, Wang Y. Electrooxidation of methanol on carbon nanotubes supported Pt-Fe alloy electrode. Electrochem. Commun. 2006, 8, 982-986.

[160] Tsai M, Yeh T, Tsai C. An improved electrodeposition technique for preparing platinum and platinum-ruthenium nanoparticles on carbon nanotubes directly grown on carbon cloth for methanol oxidation. Electrochem. Commun. 2006, 8, 1445-1452.

[161] Solla Gullon J, Lafuente E, Aldaz A, Martinez M, Feliu J. Electrochemical characterization and reactivity of Pt nanoparticles supported on single-walled carbon nanotubes. Electrochim. Acta 2007, 52, 5582-5590.

[162] Li L, Xing Y. Pt-Ru nanoparticles supported on carbon nanotubes as methanol fuel cell catalysts. J. Phys. Chem. C 2007, 111, 2803-2808.

[163] Kongkanand A, Vinodgopal K, Kuwabata S, Kamat P. Highly dispersed Pt catalysts on single-walled carbon nanotubes and their role in methanol oxidation. J. Phys. Chem. B 2006, 110, 16185-16188.

[164] Zhang W, Sherrell P, Minett AI, Razal JM, Chen J. Carbon nanotube architectures as catalyst supports for proton exchange membrane fuel cells. Energy Environ. Sci. 2010, 3, $1286-1293$.

[165] Wildgoose GG, Banks CE, Compton RG. Metal nanoparticles and related materials supported on carbon nanotubes: methods and applications. Small 2006, 2, 182-193.

[166] Banks CE, Compton RG. New electrodes for old: from carbon nanotubes to edge plane pyrolytic graphite. Analyst 2006, 131, 15-21. 
[167] Banks CE, Davies TJ, Wildgoose GG, Compton RG. Electrocatalysis at graphite and carbon nanotube modified electrodes: edge-plane sites and tube ends are the reactive sites. Chem. Commun. 2005, 829-841. Available at: http:// dx.doi.org/10.1039/B413177K.

[168] Tawfik H, Hung Y, Mahajan D. Metal bipolar plates for PEM fuel cell - a review. J. Power Sources 2007, 163, 755-767.

[169] Rao CNR, Sood AK, Subrahmanyam KS, Govindaraj A. Graphene: the new two-dimensional nanomaterial. Angew. Chem. Int. Ed. 2009, 48, 7752-7777.

[170] Neto AC, Guinea F, Peres NM. Drawing conclusions from graphene. Phys. World 2006, 19, 33.

[171] Singh V, Joung D, Zhai L, Das S, Khondaker SI, Seal S. Graphene based materials: past, present and future. Prog. Mater. Sci. 2011, 56, 1178-1271.

[172] Geim AK, Novoselov KS. The rise of graphene. Nat. Mater. 2007, 6, 183-191.

[173] Huang X, Yin Z, Wu S, Qi X, He Q, Zhang Q, Yan Q, Boey F, Zhang H. Graphene-based materials: synthesis, characterization, properties, and applications. Small 2011, 7, 1876-1902.

[174] Savage N. Materials science: super carbon. Nature 2012, 483, S30-S31.

[175] Shang N, Papakonstantinou P, Wang P, Silva S. Platinum integrated graphene for methanol fuel cells. J. Phys. Chem. C 2010, 666-669.

[176] Liang Y, Li Y, Wang H, Zhou J, Wang J, Regier T, Dai H. $\mathrm{Co}_{3} \mathrm{O}_{4}$ nanocrystals on graphene as a synergistic catalyst for oxygen reduction reaction. Nat. Mater. 2011, 10, 1-7.

[177] Wang H, Liang Y, Li Y, Dai H. $\mathrm{Co}_{1-\mathrm{x}}$ S-Graphene hybrid: a high-performance metal chalcogenide electrocatalyst for oxygen reduction. Angew. Chem. Int. Ed. 2011, 50, 10969-10972.

[178] Fan W, Lai Q, Zhang Q, Wang Y. Nanocomposites of $\mathrm{TiO}_{2}$ and reduced graphene oxide as efficient photocatalysts for hydrogen evolution. J. Phys. Chem. C 2011, 115, 10694-10701.

[179] Su C-Y, Lu A-Y, Xu Y, Chen F-R, Khlobystov AN, Li L-J. High-quality thin graphene films from fast electrochemical exfoliation. ACS Nano 2011, 5, 2332-2339.

[180] Kamat P. Graphene-based nanoarchitectures. Anchoring semiconductor and metal nanoparticles on a two-dimensional carbon support. J. Phys. Chem. Lett. 2009, 1, 520-527.

[181] Ng Y, Lightcap I, Goodwin K, Matsumura M, Kamat P. To what extent do graphene scaffolds improve the photovoltaic and photocatalytic response of $\mathrm{TiO}_{2}$ nanostructured films? J. Phys. Chem. Lett. 2010, 1, 2222-2227.

[182] Kirkland NT, Schiller T, Medhekar N, Birbilis N. Exploring graphene as a corrosion protection barrier. Corros. Sci. 2012, $56,1-4$.

[183] Prasai D, Tuberquia JC, Harl RR, Jennings GK, Bolotin KI. Graphene: corrosion-inhibiting coating. ACS Nano 2012, 6, 1102-1108.

[184] Liang Y, Wang H, Zhou J, Li Y, Wang J, Regier T, Dai H. Covalent hybrid of spinel manganese-cobalt oxide and graphene as advanced oxygen reduction electrocatalysts. J. Am. Chem. Soc. 2012, 134, 3517-3523.

[185] Mattevi C, Kim H, Chhowalla M. A review of chemical vapour deposition of graphene on copper. J. Mater. Chem. 2011, 21, 3324.

[186] Gullapalli H, Reddy ALM, Kilpatrick S, Dubey M, Ajayan PM. Graphene growth via carburization of stainless steel and application in energy storage. Small 2011, 7, 1697-1700.

[187] John R, Ashokreddy A, Vijayan C, Pradeep T. Single- and fewlayer graphene growth on stainless steel substrates by direct thermal chemical vapor deposition. Nanotechnology 2011, 22, 165701.

[188] Bae S, Kim H, Lee Y, Xu X, Park JS, Zheng Y, Balakrishnan J, Lei T, Kim HR, Song YI. Roll-to-roll production of 30-inch graphene films for transparent electrodes. Nat. Nanotechnol. 2010, 5, 574-578.

[189] Li X, Cai W, Jung IH, An JH, Yang D, Velamakanni A, Piner R, Colombo L, Ruoff RS. Synthesis, characterization, and properties of large-area graphene films. ECS Trans 2009, 19, 41-52.

[190] Van Noorden R. Production: beyond sticky tape. Nature 15, 483, S33.

[191] Gelman R, Hockett S. Renewable Energy Data Book, Kubik M, Ed., U.S. Department of Energy, 2009, pp. 1-138.

[192] Larminie J, Dicks A. Fuel Cell Systems Explained, John Wiley \& Sons Ltd.: Chichester, West Sussex, England, 2003.

[193] Urbani F, Barbera O, Giacoppo G, Squadrito G, Passalacqua E. Effect of operative conditions on a PEFC stack performance. Int. J. Hydrog. Energy 2008, 33, 3137-3141.

[194] Chu D, Jiang R. Comparative studies of polymer electrolyte membrane fuel cell stack and single cell. J. Power Sources 1999, 80, 226-234.

[195] Wang Y, Chen KS, Mishler J, Cho SC, Adroher XC. A review of polymer electrolyte membrane fuel cells: technology, applications, and needs on fundamental research. Appl. Energy 2011, 88, 981-1007.

[196] Veziroglu A, Macario R. Fuel cell vehicles: state of the art with economic and environmental concerns. Int. J. Hydrog. Energy 2011, 36, 25-43.

[197] Zhang S, Yuan X, Wang H, Merida W, Zhu H, Shen J, Wu S, Zhang J. A review of accelerated stress tests of MEA durability in PEM fuel cells. Int. J. Hydrog. Energy 2009, 34, 388-404.

[198] Yuan X-Z, Li H, Zhang S, Martin J, Wang H. A review of polymer electrolyte membrane fuel cell durability test protocols. J. Power Sources 2011, 196, 9107-9116.

[199] Wu J, Yuan XZ, Martin JJ, Wang H, Zhang J, Shen J, Wu S, Merida W. A review of PEM fuel cell durability: degradation mechanisms and mitigation strategies. J. Power Sources 2008, 184, 104-119.

[200] Schmittinger W, Vahidi A. A review of the main parameters influencing long-term performance and durability of PEM fuel cells. J. Power Sources 2008, 180, 1-14.

[201] Yu X, Yuan J, Sunde'n B. Review on the properties of nano-/ microstructures in the catalyst layer of PEMFC. J. Fuel Cell Sci. Technol. 2011, 8, 034001.

[202] Morozan A, Jousselme B, Palacin S. Low-platinum and platinum-free catalysts for the oxygen reduction reaction at fuel cell cathodes. Energy Environ. Sci. 2011, 4, 1238.

[203] Chen Z, Higgins D, Yu A, Zhang L, Zhang J. A review on non-precious metal electrocatalysts for PEM fuel cells. Energy Environ. Sci. 2011, 4, 3167-3192.

[204] Serov A, Kwak C. Review of non-platinum anode catalysts for DMFC and PEMFC application. Appl. Catal. B Environ. 2009, 90, 313-320.

[205] Bezerra C, Zhang L, Liu H, Lee K, Marques A, Marques E, Wang $\mathrm{H}$, Zhang J. A review of heat-treatment effects on activity and stability of PEM fuel cell catalysts for oxygen reduction reaction. J. Power Sources 2007, 173, 891-908.

[206] Antolini E. Catalysts for direct ethanol fuel cells. J. Power Sources 2007, 170, 1-12.

[207] Park S, Lee J-W, Popov BN. A review of gas diffusion layer in PEM fuel cells: materials and designs. Int. J. Hydrog. Energy 2012, 37, 5850-5865. 
[208] Antunes RA, Oliveira MCL, Ett G, Ett V. Corrosion of metal bipolar plates for PEM fuel cells: a review. Int. J. Hydrog. Energy 2010, 35, 3632-3647.

[209] Miller M, Bazylak A. A review of polymer electrolyte membrane fuel cell stack testing. J. Power Sources 2011, 196, 601-613.

[210] Mehta V. Review and analysis of PEM fuel cell design and manufacturing. J. Power Sources 2003, 114, 32-53.

[211] Papageorgopoulos D. DOE Fuel Cell Technology Program Overview and Introduction to the 2010 Fuel Cell Presolicitation Workshop in DOE Fuel Cell Pre-solicitation Workshop, Department of Energy: Lakewood, CO, 2010.

[212] Aoki T, Matsunaga A, Ogami Y, Maekawa A, Mitsushima S, Ota K, Nishikawa $\mathrm{H}$. The influence of polymer electrolyte fuel cell cathode degradation on the electrode polarization. J. Power Sources 2010, 195, 2182-2188.

[213] de Oliveira MCL, Ett G, Antunes RA. Materials selection for bipolar plates for polymer electrolyte membrane fuel cells using the Ashby approach. J. Power Sources 2012, 206, 3-13.

[214] Esquivel JP, Senn T, Hernández-Fernández P, Santander J, Lörgen M, Rojas S, Löchel B, Cané C, Sabaté N. Towards a compact SU-8 micro-direct methanol fuel cell. J. Power Sources 2010, 195, 8110-8115.

[215] Kamarudin SK, Achmad F, Daud WRW. Overview on the application of direct methanol fuel cell (DMFC) for portable electronic devices. Int. J. Hydrog. Energy 2009, 34, 6902-6916.

[216] Achmad F, Kamarudin SK, Daud WRW, Majlan EH. Passive direct methanol fuel cells for portable electronic devices. Appl. Energy 2011, 88, 1681-1689.

[217] Mcconnell VP. Fuel cells feed power-hungry portable electronics. Fuel Cells Bull. 2009, 2009, 12-16.

[218] Rashidi R, Dincer I, Naterer G, Berg P. Performance evaluation of direct methanol fuel cells for portable applications. J. Power Sources 2009, 187, 509-516.

[219] Stone C. Fuel cell technologies powering portable electronic devices. Fuel Cells Bull. 2007, 2007, 12-15.

[220] Apanel G, Johnson E. Direct methanol fuel cells - ready to go commercial? Fuel Cells Bull. 2004, 2004, 12-17.

[221] Joh H, Ha T, Hwang S, Kim J, Chae S, Cho J, Prabhuram J, Kim $\mathrm{S}$, Lim T, Cho B. A direct methanol fuel cell system to power a humanoid robot. J. Power Sources 2010, 195, 293-298.

[222] Kundu A, Jang J, Gil J, Jung C, Lee H, Kim S, Ku B, Oh Y. Micro-fuel cells - current development and applications. J. Power Sources 2007, 170, 67-78.

[223] Kamitani A, Morishita S, Kotaki H, Arscott S. Microfabricated microfluidic fuel cells. Sens. Actuat. B Chem. 2011, 154, 174-180.

[224] Basri S, Kamarudin SK, Daud WRW, Yaakub Z. Nanocatalyst for direct methanol fuel cell (DMFC). Int. J. Hydrog. Energy 2010, 35, 7957-7970.

[225] Liu H, Song C, Zhang L, Zhang J, Wang H, Wilkinson D. A review of anode catalysis in the direct methanol fuel cell. $J$. Power Sources 2006, 155, 95-110.

[226] Xu C, Faghri A, Li X. Improving the water management and cell performance for the passive vapor-feed DMFC fed with neat methanol. Int. J. Hydrog. Energy 2011, 36, 8468-8477.

[227] Ramya K, Dhathathreyan KS. Direct methanol fuel cells: determination of fuel crossover in a polymer electrolyte membrane. J. Electroanal. Chem. 2003, 542, 109-115.

[228] Du C, Zhao T, Yang W. Effect of methanol crossover on the cathode behavior of a DMFC: a half-cell investigation. Electrochim. Acta 2007, 52, 5266-5271.
[229] Sprague IB, Byun D, Dutta P. Effects of reactant crossover and electrode dimensions on the performance of a microfluidic based laminar flow fuel cell. Electrochim. Acta 2010, 55, 8579-8589.

[230] Lai Q-Z, Yin G-P, Wang Z-B, Du C-Y, Zuo P-J, Cheng $\mathrm{X}$-Q. Influence of methanol crossover on the fuel utilization of passive direct methanol fuel cell. Fuel Cells 2008, 8, 399-403.

[231] Xu C, Faghri A, Li X, Ward T. Methanol and water crossover in a passive liquid-feed direct methanol fuel cell. Int. J. Hydrog. Energy 2010, 35, 1769-1777.

[232] Kho BK, Bae B, Scibioh MA, Lee J, Ha HY. On the consequences of methanol crossover in passive air-breathing direct methanol fuel cells. J. Power Sources 2005, 142, 50-55.

[233] Qi Z, Kaufman A. Open circuit voltage and methanol crossover in DMFCs. J. Power Sources 2002, 110, 177-185.

[234] Zhao TS, Yang WW, Chen R, Wu QX. Towards operating direct methanol fuel cells with highly concentrated fuel. J. Power Sources 2010, 195, 3451-3462.

[235] Liu JG, Zhao TS, Liang ZX, Chen R. Effect of membrane thickness on the performance and efficiency of passive direct methanol fuel cells. J. Power Sources 2006, 153, 61-67.

[236] Park YC, Kim DH, Lim S, Kim SK, Peck DH, Jung DH. Design of a MEA with multi-layer electrodes for high concentration methanol DMFCs. Int. J. Hydrog. Energy 2011, 37, 4717-4727.

[237] Jayashree RS, Gancs L, Choban ER, Primak A, Natarajan D, Markoski LJ, Kenis PJA. Air-breathing laminar flow-based microfluidic fuel cell. J. Am. Chem. Soc. 2005, 127, 1675816759.

[238] Jayashree RS, Yoon SK, Brushett FR, Lopez-Montesinos PO, Natarajan D, Markoski LJ, Kenis PJA. On the performance of membraneless laminar flow-based fuel cells. J. Power Sources 2010, 195, 3569-3578.

[239] Kjeang E, Djilali N, Sinton D. Microfluidic fuel cells: a review. J. Power Sources 2009, 186, 353-369.

[240] Mousavi Shaegh SA, Nguyen NT, Chan SH. A review on membraneless laminar flow-based fuel cells. Int. J. Hydrog. Energy 2011, 35, 5675-5694.

[241] Ho B, Kjeang E. Microfluidic fuel cell systems. Cent. Eur. J. Eng. 2011, 1, 123-131.

[242] Lee JW, Kjeang E. A perspective on microfluidic biofuel cells. Biomicrofluidics 2010, 4, 041301.

[243] Ferrigno R, Stroock A, Clark T, Mayer M, Whitesides G. Membraneless vanadium redox fuel cell using laminar flow. J. Am. Chem. Soc. 2002, 124, 12930-12931.

[244] Thorson MR, Brushett FR, Timberg CJ, Kenis PJA. Design rules for electrode arrangement in an air-breathing alkaline direct methanol laminar flow fuel cell. J. Power Sources 2012, 218, 28-33.

[245] Whipple DT, Finke EC, Kenis PJA. Microfluidic reactor for the electrochemical reduction of carbon dioxide: the effect of pH. Electrochem. Solid-State Lett. 2010, 13, B109.

[246] Hollinger AS, Maloney RJ, Jayashree RS, Natarajan D, Markoski LJ, Kenis PJA. Nanoporous separator and low fuel concentration to minimize crossover in direct methanol laminar flow fuel cells. J. Power Sources 2010, 1-6.

[247] Brushett F, Duong H, Wei J, Behrens R, Wieckowski A, Kenis $\mathrm{P}$. Investigation of $\mathrm{Pt}, \mathrm{PtCo}$, and $\mathrm{PtCo} / \mathrm{Mo}$ cathodes for the ORR in a microfluidic $\mathrm{H} / \mathrm{O}$ fuel cell. J. Electrochem. Soc. 2010, 157, B837.

[248] Whipple DT, Jayashree RS, Egas D, Alonso-Vante N, Kenis PJA. Ruthenium cluster-like chalcogenide as a methanol 
tolerant cathode catalyst in air-breathing laminar flow fuel cells. Electrochim. Acta 2009, 54, 4384-4388.

[249] Kenis P, Jayashree R, Brushett F, Hollinger A, Natarajan D, Markoski L. Laminar flow fuel cells: from concept to multichannel prototype. In 216th ECS Meeting, The Electrochemical Society: Vienna, Austria, 2009, Abstract no. 1136.

[250] Brushett F, Jayashree R, Zhou W, Kenis P. Investigation of fuel and media flexible laminar flow-based fuel cells. Electrochim. Acta 2009, 54, 7099-7105.

[251] Hollinger A, Maloney R, Markoski L, Kenis P. Nanoporous separator to minimize fuel crossover in a direct methanol laminar flow fuel cell. In 214th ECS Meeting, The Electrochemical Society: Honolulu, Hawaii, USA, 2008, Abstract \#701.

[252] Markoski L, Primak A, Kenis PJ. Improved performance of direct methanol laminar flow fuel cells. In 207th ECS Meeting, The Electrochemical Society: Quebec, CA, 2005, 10, B23, Abstract \#137.

[253] Jayashree R, Mitchell M, Natarajan D, Markoski L, Kenis P. Microfluidic hydrogen fuel cell with a liquid electrolyte. Langmuir 2007, 23, 6871-6874.

[254] Natarajan D, Primak A, Kenis PJA, Markoski LJ. Air-breathing multi-channel laminar flow fuel cells. In 209th ECS Meeting, The Electrochemical Society: Denver, Colorado, USA, 2006, Abstract \#1155.

[255] Jayashree R, Egas D, Spendelow J, Natarajan D, Markoski L, Kenis P. Air-breathing laminar flow-based direct methanol fuel cell with alkaline electrolyte. Electrochem. Solid-State Lett. 2006, 9, A252.

[256] Jayashree R, Egas D, Natarajan D, Spendelow J, Markoski L, Kenis P. Fuel and media flexible air-breathing laminar flow fuel cells. In 209th ECS Meeting, The Electrochemical Society: Denver, Colorado, USA, 2006, Abstract \#1156.

[257] Yoon S, Mitchell M, Choban E, Kenis P. Gravity-induced reorientation of the interface between two liquids of different densities flowing laminarly through a microchannel. Lab Chip 2005, 5, 1259-1263.

[258] Choban ER, Gancs L, Spendelow JS, Wieckowski A, Kenis PJ. Laminar flow-based micro fuel cells: opportunities for alkaline and 'mixed-media' fuel cell catalysis. In 207th ECS Meeting, The Electrochemical Society: Quebec, Canada, 2005, Abstract \#1558.

[259] Choban E, Markoski L, Wieckowski A, Kenis P. Microfluidic fuel cell based on laminar flow. J. Power Sources 2004, 128, 54-60.

[260] Jayashree RS, Zhou W-P, Brushett FR, Kenis PJA. Direct ethanol laminar flow fuel cell. In 212th ECS Meeting, The Electrochemical Society: Washington, DC, USA, 2007, Abstract \#604.

[261] Bazylak A, Sinton D, Djilali N. Improved fuel utilization in microfluidic fuel cells: a computational study. J. Power Sources 2005, 143, 57-66.

[262] Wang H, Leung DY, Xuan J. Modeling of an air cathode for microfluidic fuel cells: transport and polarization behaviors. Int. J. Hydrog. Energy 2011, 36, 14704-14718.

[263] Kjeang E, Michel R, Harrington DA, Djilali N, Sinton D. A microfluidic fuel cell with flow-through porous electrodes. J. Am. Chem. Soc. 2008, 130, 4000-4006.

[264] Gago AS, Morales-Acosta D, Arriaga LG, Alonso-Vante N. Carbon supported ruthenium chalcogenide as cathode catalyst in a microfluidic formic acid fuel cell. J. Power Sources 2011, 196, 1324-1328.

[265] Gago AS, Timperman L, Alonso-Vante N. $\mathrm{Ru}_{\mathrm{x}} \mathrm{Se}_{\mathrm{y}}$ cluster-like as cathode catalyst in a formic acid laminar flow fuel cell. In
EFCF 2011 Proceedings, European Fuel Cell Forum: Lucerne, Switzerland, 2011, Session A09-04/57.

[266] Gago AS, Gochi-Ponce Y, Feng Y-J, Esquivel JP, Sabaté N, Santander J, Alonso-Vante N. Novel tolerant chalcogenide cathodes of membraneless micro-fuel cells. ChemSusChem 2012, 5, 1488-1494.

[267] Xuan J, Leung DYC, Leung MKH, Ni M, Wang H. A computational study of bifunctional oxygen electrode in air-breathing reversible microfluidic fuel cells. Int. J. Hydrog. Energy 2011, 36, 9231-9241.

[268] Xuan J, Leung M, Leung D, Wang H. Towards orientationindependent performance of membraneless microfluidic fuel cell: understanding the gravity effects. Appl. Energy 2012, 90, 80-86.

[269] Shyu J, Wei C, Lee C, Wang C. Investigation of bubble effect in microfluidic fuel cells by a simplified microfluidic reactor. Appl. Therm. Eng. 2010, 30, 1863-1871.

[270] Zebda A, Renaud L, Cretin M, Innocent C, Pichot F, Ferrigno R, Tingry S. Electrochemical performance of a glucose/oxygen microfluidic biofuel cell. J. Power Sources 2009, 193, 602-606.

[271] Feng Y, He T, Alonso-Vante N. Oxygen reduction reaction on carbon-supported $\mathrm{CoSe}_{2}$ nanoparticles in an acidic medium. Electrochim. Acta 2009, 54, 5252-5256.

[272] Feng YJ, He T, Alonso-Vante N. Carbon-supported $\mathrm{CoSe}_{2}$ nanoparticles for oxygen reduction reaction in acid medium. Fuel Cells 2010, 10, 77-83.

[273] Wang R, Liao S, Liu H, Meng H. Synthesis and characterization of $\mathrm{Pt}-\mathrm{Se} / \mathrm{C}$ electrocatalyst for oxygen reduction and its tolerance to methanol. J. Power Sources 2007, 171, 471-476.

[274] Gochi-Ponce Y, Alonso-Nunez G, Alonso-Vante N. Synthesis and electrochemical characterization of a novel platinum chalcogenide electrocatalyst with an enhanced tolerance to methanol in the oxygen reduction reaction. Electrochem. Commun. 2006, 8, 1487-1491.

[275] Alonso-Vante N, Schubert B, Tributsch H. Transition metal cluster materials for multi-electron transfer catalysis. Mater. Chem. Phys. 1989, 22, 281-307.

[276] Alonso-Vante N, Bogdanoff P, Tributsch H. On the origin of the selectivity of oxygen reduction of ruthenium-containing electrocatalysts in methanol-containing electrolyte. J. Catal. 2000, 190, 240-246.

[277] Alonso-Vante N. Chevrel phase and cluster-like chalcogenide materials. In Handbook of Fuel Cells - Fundamentals, Technology and Applications, Vielstich W, Lamn A, Gasteiger H, Eds., Wiley: Chichester, 2003, pp. 534-543.

[278] Bruce PG, Freunberger SA, Hardwick LJ, Tarascon J-M. Li$\mathrm{O}_{2}$ and $\mathrm{Li}-\mathrm{S}$ batteries with high energy storage. Nat. Mater. 2011, 11, 19-29.

[279] Kraytsberg A, Ein-Eli Y. Review on Li "air batteries". Opportunities, limitations and perspective. J. Power Sources 2011, 196, 886-893.

[280] He H, Niu W, Asl NM, Salim J, Chen R, Kim Y. Effects of aqueous electrolytes on the voltage behaviors of rechargeable Li-air batteries. Electrochim. Acta 2012, 67, 87-94.

[281] Lu Y-C, Xu Z, Gasteiger HA, Chen S, Hamad-Schifferli K, Shao-Horn Y. Platinum-gold nanoparticles: a highly active bifunctional electrocatalyst for rechargeable lithium-air batteries. J. Am. Chem. Soc. 2010, 132, 12170-12171.

[282] Zhang SS, Foster D, Read J. Discharge characteristic of a nonaqueous electrolyte $\mathrm{Li} / \mathrm{O}_{2}$ battery. J. Power Sources 2010, 195, 1235-1240. 
[283] Laoire CO, Mukerjee S, Abraham KM, Plichta EJ, Hendrickson MA. Elucidating the mechanism of oxygen reduction for lithium-air battery applications. J. Phys. Chem. C 2009, 113, 20127-20134.

[284] Song M-K, Park S, Alamgir FM, Cho J, Liu M. Nanostructured electrodes for lithium-ion and lithium-air batteries: the latest developments, challenges, and perspectives. Mater. Sci. Eng. Rep. 2011, 72, 203-252.

[285] Hummelshoj JS, Blomqvist J, Datta S, Vegge T, Rossmeisl J, Thygesen KS, Luntz AC, Jacobsen KW, Norskov JK. Communications: elementary oxygen electrode reactions in the aprotic Li-air battery. J. Chem. Phys. 2010, 132, 071101.

[286] Débart A, Paterson AJ, Bao J, Bruce PG. $\alpha-\mathrm{MnO}_{2}$ nanowires: a catalyst for the $\mathrm{O}_{2}$ electrode in rechargeable lithium batteries. Angew. Chem. Int. Ed. 2008, 47, 4521-4524.

[287] Débart A, Bao J, Armstrong G, Bruce PG. An $\mathrm{O}_{2}$ cathode for rechargeable lithium batteries: the effect of a catalyst. J. Power Sources 2007, 174, 1177-1182.

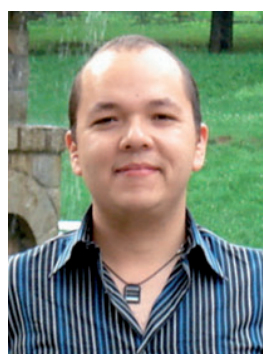

Aldo S. Gago is a physicist graduated from University of Guadalajara, Mexico. In 2011, he received his doctoral degree from University of Poitiers, France under supervision of Prof. Nicolas Alonso-Vante. His thesis work consisted in developing materials and systems for (photo) electrochemical energy conversion. At present, he is a postdoctoral fellow at the German Aerospace Center (DLR), under the auspices of DAAD. His main interests are nanostructured materials, corrosion and hydrogen technologies.

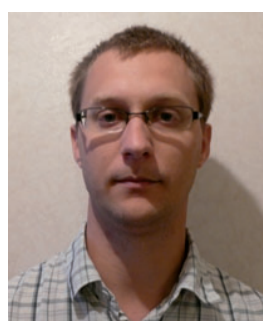

Aurelien Habrioux holds a master's degree in materials science and he completed his $\mathrm{PhD}$ with Prof. B. Kokoh at the University of Poitiers in 2009 where he specifically studied the existing correlation between structural properties of noble metal-based nanoparticles and their electrocatalytic activity towards glucose molecule. He was a postdoctoral researcher at CEA Saclay, France, studying the insertion of Li ions into nanostructured mineral host matrix by nuclear microanalysis. He is currently assistant professor at the University of Poitiers working on the synthesis of new nanomaterials for electrochemical energy conversion devices.
[288] Wang Y, Zhou H. A lithium-air battery with a potential to continuously reduce $\mathrm{O}_{2}$ from air for delivering energy. J. Power Sources 2010, 195, 358-361.

[289] Gao M-R, Xu Y-F, Jiang J, Zheng Y-R, Yu S-H. Water oxidation electrocatalyzed by an efficient $\mathrm{Mn}_{3} \mathrm{O}_{4} / \mathrm{CoSe}_{2}$ nanocomposite. J. Am. Chem. Soc. 2012, 134, 2930-2933.

[290] Liang Y, Li Y, Wang H, Zhou J, Wang J, Regier T, Dai H. $\mathrm{Co}_{3} \mathrm{O}_{4}$ nanocrystals on graphene as a synergistic catalyst for oxygen reduction reaction. Nat. Mater. 2011, 10, 780-786.

[291] Lu Y-C, Gasteiger HA, Shao-Horn Y. Catalytic activity trends of oxygen reduction reaction for nonaqueous $\mathrm{Li}$-air batteries. J. Am. Chem. Soc. 2011, 133, 19048-19051.

[292] Cheng H, Scott K. Selection of oxygen reduction catalysts for rechargeable lithium "air batteries": metal or oxide? Appl. Catal. B Environ. 2011, 108-109, 140-151.

Received August 10, 2012; accepted September 10, 2012

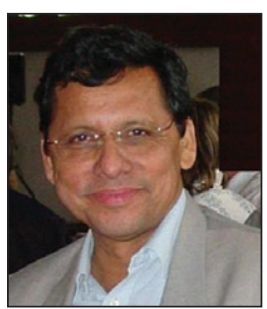

Professor Nicolas Alonso-Vante has developed materials in the nanodivided scale based on transition metal and chalcogenides in metallic and semiconducting form in Germany and France. Using facile chemical routes he has pioneered the use of non-platinum and non-precious metal catalysts center chalcogenides in order to understand the complex process of the oxygen reduction reaction process, an important technological reaction in low temperature fuel cells. He has received the awards of the Alexander von Humboldt foundation fellowship, of the National Polytechnic Institute-Mexico as a R\&D distinguished graduate, and of the Mexican Council of Technology SNI-III recognition as a Mexican researcher working outside Mexico. 